\title{
Characterization of photochemical pollution at different elevations in mountainous areas in Hong Kong
}

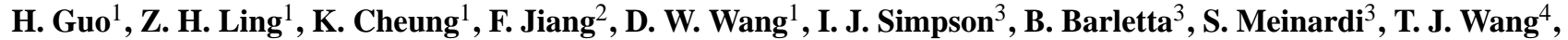 \\ X. M. Wang ${ }^{5}$, S. M. Saunders ${ }^{6}$, and D. R. Blake ${ }^{3}$ \\ ${ }^{1}$ Air Quality Studies, Department of Civil and Environmental Engineering, The Hong Kong Polytechnic University, \\ Hong Kong, China \\ ${ }^{2}$ International Institute for Earth System Science, Nanjing University, Nanjing, China \\ ${ }^{3}$ Department of Chemistry, University of California at Irvine, California, USA \\ ${ }^{4}$ School of Atmospheric Sciences, Nanjing University, Nanjing, China \\ ${ }^{5}$ Guangzhou Institute of Geochemistry, Chinese Academy of Sciences, Guangzhou, China \\ ${ }^{6}$ School of Biomedical, Biomolecular and Chemical Sciences, University of Western Australia, Perth, Australia
}

Correspondence to: H. Guo (ceguohai@ polyu.edu.hk)

Received: 24 August 2012 - Published in Atmos. Chem. Phys. Discuss.: 12 November 2012

Revised: 18 February 2013 - Accepted: 25 March 2013 - Published: 16 April 2013

\begin{abstract}
To advance our understanding on the factors that affect photochemical pollution at different elevations in mountainous areas, concurrent systematic field measurements (September to November 2010) were conducted at a mountain site and at an urban site at the foot of the mountain in Hong Kong. The mixing ratios of air pollutants were greater at the foot of the mountain (i.e., Tsuen Wan urban site, TW) than near the summit (i.e., Tai Mao Shan mountain site, TMS), expect for ozone. In total, only one $\mathrm{O}_{3}$ episode day was observed at TW, whereas twenty-one (21) $\mathrm{O}_{3}$ episode days were observed at TMS. The discrepancy of $\mathrm{O}_{3}$ at the two sites was attributed to the mixed effects of NO titration, vertical meteorological conditions, regional transport and mesoscale circulations. The lower NO levels at TMS and the smaller differences of "oxidant" $\mathrm{O}_{\mathrm{x}}\left(\mathrm{O}_{3}+\right.$ $\mathrm{NO}_{2}$ ) between the two sites suggested that variations of $\mathrm{O}_{3}$ at the two sites were partly attributed to different degree of NO titration. In addition, analysis of vertical structure of meteorological variables revealed that the inversion layer at the range of altitudes of 500-1000 m might be another factor that caused the high $\mathrm{O}_{3}$ levels at TMS. Furthermore, analyses of the wind fields, the levels of air pollutants in different air flows, ratios of different trace gases and the correlation between variability and the lifetime of VOCs (volatile organic compounds) indicated that high $\mathrm{O}_{3}$ concentrations at TMS were somewhat influenced by regional air masses from the
\end{abstract}

highly polluted Pearl River delta (PRD) region. In particular, the diurnal profiles and correlations of gaseous pollutants suggested influence of mesoscale circulations, which is confirmed using the Master Chemical Mechanism moving box model (Mbox) and the Weather Research and Forecasting (WRF) model. By investigating the correlations of observed $\mathrm{O}_{3}$ and $\mathrm{NO}_{\mathrm{x}}^{*}$ and the relationships of $\mathrm{O}_{3}$ and its precursors by an observation-based model (OBM), as well as the ratios of $\mathrm{VOC} / \mathrm{NO}_{\mathrm{x}}$, it was concluded that photochemical $\mathrm{O}_{3}$ formation at TMS was mostly influenced by VOCs, with measurable impact of $\mathrm{NO}_{\mathrm{x}}$, while $\mathrm{O}_{3}$ production at TW was generally limited by the concentrations of VOCs. This is the first report of the comprehensive analysis on the data of photochemical pollution obtained from concurrent measurements in mountainous areas in the PRD region.

\section{Introduction}

Distinguished from surface measurements and aircraft observations, studies conducted in mountain areas often provide information on the regional background concentrations of air pollutants, the influence of regional transport and mesoscale circulations, the photochemistry of biogenic volatile organic compounds (BVOCs), and the influence of meteorological factors on ozone $\left(\mathrm{O}_{3}\right)$ chemistry (Pochanart et al., 2003; 
Zellweger et al., 2003; Gao et al., 2005; Wang et al., 2006; $\mathrm{Fu}$ et al., 2010). The characteristics of $\mathrm{O}_{3}$ in mountainous areas have been investigated in different locations in recent years (e.g., Evtyugina et al., 2009; Scott and Ahmet, 2009; Crowley et al., 2010). For example, Burley and Bytnerowicz (2011) investigated the $\mathrm{O}_{3}$ distribution at the White Mountains (1237-4342 m) in California and concluded that high $\mathrm{O}_{3}$ concentrations were correlated with slow-moving backtrajectories that had spent more time inland and less time offshore. Monteiro et al. (2012) analyzed a high $\mathrm{O}_{3}$ episode by a statistical technique and a modeling approach at a mountain site $(1086 \mathrm{~m})$ in the Mediterranean region, and reported that transport of $\mathrm{O}_{3}$ and its precursors by local mountain breezes and sea-breeze circulation was mainly responsible for the high $\mathrm{O}_{3}$ concentrations. Turnipseed et al. (2004) simulated the mesoscale atmospheric flow conditions influenced by regional topography in the Niwot Ridge AmeriFlux site within the Rocky Mountains ( $3050 \mathrm{~m}$ ), and significant influence of mesoscale winds was found under the strong synoptic westerly winds. Ou Yang et al. (2012) investigated the seasonal and diurnal variations of $\mathrm{O}_{3}$ at a high-altitude mountain site $(2862 \mathrm{~m})$ in central Taiwan and concluded that the springtime maximum $\mathrm{O}_{3}$ concentration was most likely caused by the long-range transport of air masses from Southeast Asia.

In mainland China, limited studies have been undertaken to investigate the characteristics of $\mathrm{O}_{3}$ pollution in mountainous areas (e.g., Gao et al., 2005; Wang et al., 2006; Li et al., 2008; Xue et al., 2011). Gao et al. (2005) reported measurements of $\mathrm{O}_{3}$ and $\mathrm{CO}$ at the summit of Mt. Tai (1534 m) and suggested that air masses from the North China Plains or the recirculation over the Shandong Peninsula had significant influence on air pollutants. Li et al. (2008) investigated the impact of chemical production and transport on summer diurnal $\mathrm{O}_{3}$ behavior at a mountainous site in the North China Plain. They suggested that in situ chemistry accounted for most of the $\mathrm{O}_{3}$ increment from morning to mid-afternoon. Wang et al. (2006) and Xue et al. (2011) studied the origin of surface $\mathrm{O}_{3}$ and reactive nitrogen speciation at Mt. Waliguan $(3816 \mathrm{~m})$ in western China, and indicated that high $\mathrm{O}_{3}$ events were mostly derived from the downward transport of the upper tropospheric air rather than anthropogenic pollution. Nonetheless, all of these studies were carried out only at mountain sites in northern/western China.

Hong Kong and the rest of Pearl River delta (PRD) region are situated along the coast of southern China. The rapid economic development has caused elevated levels of air pollution in this region (Huang et al., 2006; Guo et al., 2009). Owning to its critical role in the atmospheric oxidizing capacity, human health and vegetation (NRC, 1991; PORG, 1997; IPCC, 2007), photochemical $\mathrm{O}_{3}$ has been studied in Hong Kong and the PRD region for the past two decades (Chan et al., 1998a, b; Wang et al., 2003; Ding et al., 2004; Zhang et al., 2007; Guo et al., 2009). Though these studies help us to better understand the $\mathrm{O}_{3}$ pollution in the PRD re- gion, they were conducted at low-elevation urban and rural sites $(<50 \mathrm{~m})$.

Many studies showed that mesoscale circulations like sealand breezes and/or mountain-valley breezes play important roles in air pollution transport in such a region with complex topography and land use/land cover. The role of sealand breezes in air pollution transport has been well-studied previously (Zhang and Zhang, 1997; Liu et al., 2000; Ding et al., 2004). For mountain-valley breezes, there were relatively few Hong Kong studies focusing on this topic, even though it is almost certainly very important to air pollution transport in Hong Kong, where topography and physical features are complex and where about $75 \%$ of the land area is hilly (AFCD, 2008). In addition, there were very few works conducting field measurements at a mountain site, especially the concurrent measurements at the foot and summit of the mountain in this region. To investigate the variations of $\mathrm{O}_{3}$ at the mountain site and low-elevation location, the influence of mesoscale circulation/regional transport on air pollutants and the relationship between $\mathrm{O}_{3}$ and its precursors at mountainous areas, concurrent field measurements including air pollutants and meteorological conditions were conducted in a mountain site and an urban site at the foot of the mountain. The characteristics of air pollutants and the causes of variations of air pollutants at the two sites were investigated; the relationships between the two sites and the influence of mesoscale circulations were explored by integrated data analysis and different models, and the relationships of $\mathrm{O}_{3}$-precursors at the two different sites were further evaluated. To our best knowledge, this is the first attempt to conduct these concurrent measurements and comprehensive analysis of air pollutants in the mountainous area in this region.

\section{Methodologies}

\subsection{Site description}

In this study, field measurements were carried out simultaneously at different elevations at the highest mountain in Hong Kong, Mt. Tai Mo Shan (Mt. TMS) (Fig. 1). Sampling was conducted from 6 September to 29 November 2010, when high $\mathrm{O}_{3}$ mixing ratios were frequently observed in this season (So and Wang, 2003; Wang et al., 2005). The Hong Kong Environmental Protection Department (HKEPD) air quality monitoring station at Tsuen Wan (TW) - the closest HKEPD monitoring station at the foot of Mt. TMS - was selected as the measurement site at the foot of the mountain $\left(22.373^{\circ} \mathrm{N}\right.$, $114.112^{\circ} \mathrm{E}$, elevation of $10 \mathrm{~m}$ ). Tsuen Wan (TW) is a mixed residential, commercial and light industrial area in the New Territories in Hong Kong. The site is adjacent to a main traffic road and surrounded by residential and industrial blocks. The high-elevation site (TMS) was set up on the rooftop of a building at Mt. TMS $\left(22.405^{\circ} \mathrm{N}, 114.118^{\circ} \mathrm{E}\right)$ at an elevation 
of $640 \mathrm{~m}$. The TW and TMS sites are separated by a straight line distance of about $7 \mathrm{~km}$ and an elevation of $630 \mathrm{~m}$.

Mt. TMS is surrounded by 1440 ha of natural territory and borders with the Tai Po Kau Nature Reserve to the east, Shing Mun Country Park to the south, Route Twisk highway and Tai Lam Country Park to the west, and the old valley of the Lam Tsuen to the north (AFCD, 2008). Surrounding the foot of the mountain are urban centers with a population of 2.23 million, including Tsuen Wan, Sha Tin, Tuen Mun and Yuen Long areas. The straight distances between the mountain summit and the urban centers at the foot are about 5$10 \mathrm{~km}$. Further to the south are the urban centers of the partial New Territory, Kowloon Peninsula, Hong Kong Island and the South China Sea. To the southwest are the newlydeveloped residential area of Tung Chung, the Hong Kong international airport, and the South China Sea. Because of its unique topography, mesoscale circulations, i.e., mountainvalley breezes and sea-land breezes, are often observed at Mt. TMS, which would enhance the interaction of polluted urban air and the mountain air.

\subsection{Measurement techniques}

\subsubsection{Continuous measurements of $\mathrm{O}_{3}, \mathrm{CO}, \mathrm{SO}_{2}$ and $\mathrm{NO}_{\mathrm{x}}$}

Hourly data of $\mathrm{O}_{3}, \mathrm{CO}, \mathrm{SO}_{2}, \mathrm{NO}-\mathrm{NO}_{2}-\mathrm{NO}_{\mathrm{x}}$ and meteorological parameters at TW were obtained from the HKEPD (Hong Kong Environmental Protection Department, http:// epic.epd.gov.hk/ca/uid/airdata). Detailed information about the measurements, quality assurance and control protocols can be found in the HKEPD report (HKEPD, 2012). At TMS, sampling instruments were installed in a room of a building and ambient air samples were drawn through a $5 \mathrm{~m}$ long perfluoroalkoxy (PFA) Teflon tube (OD: $12.7 \mathrm{~mm}$; ID: $9.6 \mathrm{~mm}$ ). The inlet of the sampling tube was located $2 \mathrm{~m}$ above the rooftop of the building and was connected to a PFA manifold with a bypass pump drawing air at a rate of $5 \mathrm{~L} \mathrm{~min}^{-1}$ into the intakes of the analyzers for $\mathrm{O}_{3}, \mathrm{CO}, \mathrm{SO}_{2}$ and $\mathrm{NO}-\mathrm{NO}_{2}-\mathrm{NO}_{\mathrm{x}}$.

$\mathrm{O}_{3}$ was measured using a commercial UV photometric instrument (Advanced Pollution Instrumentation (API), model $400 \mathrm{E}$ ) with a detection limit of $0.6 \mathrm{ppbv}$. This analyzer was calibrated by a transfer standard (Thermo Environmental Instruments (TEI) 49PS) prior to the field studies. Sulfur dioxide was measured with a pulsed UV fluorescence (API, model 100E) with a detection limit of $0.4 \mathrm{ppbv}$ and $2 \sigma$ precision of $0.5 \%$ for ambient levels of $50 \mathrm{ppbv}$ ( $2 \mathrm{~min}$ average). Carbon monoxide was measured with a gas filter correlation, nondispersive infrared analyzer (API, Model 300E) with a heated catalytic scrubber to convert $\mathrm{CO}$ to $\mathrm{CO}_{2}$ for baseline determination. Zeroing was conducted every $2 \mathrm{~h}$ for $12 \mathrm{~min}$. The $2 \mathrm{~min}$ data at the end of each zeroing were taken as the baseline. The detection limit was $30 \mathrm{ppbv}$ for a 2 min average. The $2 \mathrm{~s}$ precision was about $1 \%$ for a $\mathrm{CO}$ level of $500 \mathrm{ppbv}$ ( $2 \mathrm{~min}$ average) and the overall uncer- tainty was estimated to be $10 \%$. Oxides of nitrogen were detected using a commercial chemiluminescence with an internal molybdenum converter (API, Model 200E) and a detection limit of $0.4 \mathrm{ppbv}$. The analyzers were calibrated daily by injecting scrubbed ambient air (TEI, Model 111) and a span gas mixture. A NIST (National Institute of Standards and Technology)-traceable standard (Scott-Marrin, Inc.) containing $156.5 \mathrm{ppmv} \mathrm{CO}( \pm 2 \%), 15.64 \mathrm{ppmv} \mathrm{SO}_{2}( \pm 2 \%)$, and 15.55 ppmv NO $( \pm 2 \%)$ was diluted using a dynamic calibrator (Environics, Inc., Model 6100). For the $\mathrm{O}_{3}, \mathrm{SO}_{2}, \mathrm{CO}$ and $\mathrm{NO}-\mathrm{NO}_{2}-\mathrm{NO}_{\mathrm{x}}$ analyzers, a data logger (Environmental Systems Corporation, Model 8832) was used to control the calibrations and to collect data, which were averaged to $1 \mathrm{~min}$ intervals.

Meteorological parameters, including temperature, solar radiation, relative humidity, wind speed and wind direction, were monitored by a weather station (Vantage Pro TM \& Vantage Pro 2 plus TM Weather Stations, Davis Instruments).

\subsubsection{Sampling and analysis of VOCs}

Concurrent VOC samples were collected on selected non- $\mathrm{O}_{3}$ episode (i.e., 28 September; 2, 8, 14, 18-19, 27-28 October; and 20-21 November) and $\mathrm{O}_{3}$ episode days (i.e., 2324, 29-31 October; 1-3, 9 and 19 November) at both sites. The potentially high $\mathrm{O}_{3}$ episode days were selected based on weather prediction and meteorological data analysis, and were generally related to stronger solar radiation, lower wind speeds, and less vertical dilution of air pollution compared to non- $\mathrm{O}_{3}$ episode days. These $\mathrm{O}_{3}$ episode and non- $\mathrm{O}_{3}$ episode days were later confirmed by the observed $\mathrm{O}_{3}$ mixing ratios. In this study, an $\mathrm{O}_{3}$ episode day is defined when the peak $1 \mathrm{~h}$ average $\mathrm{O}_{3}$ mixing ratio exceeds $100 \mathrm{ppbv}$ (i.e., China's Grade II standard). Ambient VOC samples were collected using cleaned and evacuated $2 \mathrm{~L}$ electro-polished stainless steel canisters. The canisters were prepared and delivered to Hong Kong by the Rowland/Blake group at University of California, Irvine (UCI). A flow-controlling device was used to collect $1 \mathrm{~h}$ integrated samples. During non- $\mathrm{O}_{3}$ episode days, VOC samples were collected at $2 \mathrm{~h}$ intervals from 07:00 to 19:00 LT (local time) per day at both sites. For $\mathrm{O}_{3}$ episode days, hourly samples were consecutively collected from 09:00 to 16:00 LT, with additional samples collected at 18:00, 21:00, 00:00, 03:00 and 07:00 LT. Due to logistic issues, 19 additional samples were collected at TMS, and one additional sample was taken at TW. Totally, 201 and 183 VOC samples were collected at TMS and TW, respectively.

Before sampling, all canisters were cleaned at least five times by repeatedly filling and evacuating with humidified pure nitrogen gas $\left(\mathrm{N}_{2}\right)$. To test for any contamination in the canister, the evacuated canister was filled with pure $\mathrm{N}_{2}$, stored for at least $24 \mathrm{~h}$, then checked by the same VOC analytical methods to ensure that all the target compounds 


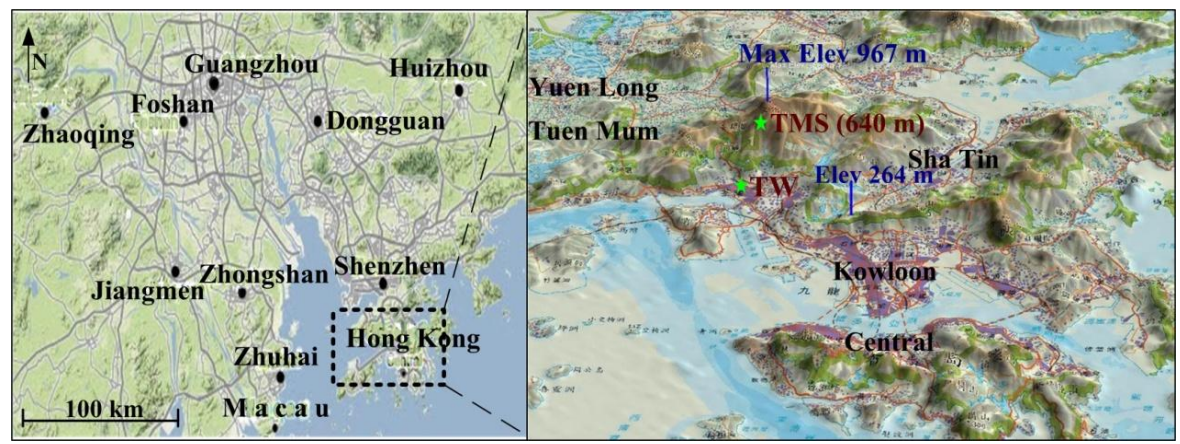

Fig. 1. The sampling sites and the surrounding environment.

were not found or were under the method detection limit (MDL). In addition, duplicate samples were regularly collected to check the precision and reliability of the sampling and analytical methods. After sampling, the VOC samples were returned to the laboratory at UCI for chemical analysis. The analytical system, which is fully described in Simpson et al. (2010), uses multicolumn gas chromatography (GC) with five column-detector combinations. The oven parameters employed for each GC can be found in Colman et al. (2001).

VOCs were identified by their retention times and their mass spectra. The quantification of target VOCs was accomplished using multipoint external calibration curves, a combination of National Bureau of Standards, Scott Specialty Gases (absolute accuracy estimated to be within $\pm 5 \%$ ) and UCI made standards. The detection limit, measurement precision and accuracy for each VOC varies by compound class and is listed in Simpson et al. (2010). Generally, alkanes, alkenes and aromatics have a detection limit of 3 pptv, a precision of $3 \%$, and an accuracy of $5 \%$.

\subsection{WRF simulation}

The Weather Research and Forecasting (WRF) model is a next-generation mesoscale numerical weather prediction system designed to serve both operational forecasting and atmospheric research needs (Skamarock and Klemp, 2008). It is suitable for use in a broad spectrum of applications across scales ranging from meters to thousands of kilometres (http://wrf-model.org/index.php). Simulations and real-time forecasting tests have indicated that the WRF model has a good performance for weather forecasts, and has broad application prospects (Steven et al., 2004; Done et al., 2004). A detailed description can be found in Guo et al. (2009).

As mountain-valley breezes are small-scale weather phenomena caused by thermal forcing, and there is a complex terrain in Hong Kong (AFCD, 2008), considerably high model resolution is needed to capture these breezes. In this study, the mountain-valley breezes were simulated using a domain system of five nested grids $(36,12,4,1.333$, and
$0.444 \mathrm{~km})$. The domain with finest resolution $(0.444 \mathrm{~km}$ grid $)$ covers the Hong Kong region. In the vertical scale, there were 31 sigma levels for all five domains, with the model top fixed at $100 \mathrm{hPa}$. For physical processes, the WRF singlemoment 3-class microphysics scheme (Hong et al., 2004), RRTM (Rapid Radiative Transfer Model) long-wave radiation scheme (Mlawer et al., 1997), Goddard short-wave radiation scheme (Chou and Suarez, 1994), MM5 (Mesoscale Model v5) similarity surface layer (Zhang and Anthes, 1982), Noah land surface model coupled with urban canopy model (Chen and Dudhia, 2001), and the Yonsei planetary boundary-layer scheme (Hong et al., 2006) were applied for all domains. The Grell-Devenyi ensemble cumulus parameterization scheme (Grell and Dévényi, 2002) was applied for the outer three domains, while there was no cumulus parameterization scheme for the inner two domains. In addition, the distribution of urban land cover was replaced using the latest data downloaded from http://webmap.ornl.gov.

\subsection{Master Chemical Mechanism box (Mbox) model simulation}

In this study, a photochemical box model (PBM) implementing the most up-to-date version of near-explicit photochemical mechanism, namely the Master Chemical Mechanism version 3.2 (MCMv3.2), has been applied to simulated the $\mathrm{O}_{3}$ pollution at the two sites (Lam et al., 2013). MCMv3.2 was employed to describe the photochemical degradation in this study, including 143 VOCs in 16500 reactions (Jenkin et al., 1997, 2003; Saunders et al., 2003; Bloss et al., 2005). The mechanism is accessible via the website: http://mcm. leeds.ac.uk/MCM. Three model scenarios were considered in this study: (1) Stationary photochemical box in TW: in this scenario, the monitoring station at TW is assumed to be the center of the box model and the concentrations of the targeted species are homogenous throughout the box. Hence, the model in scenario 1 is constrained with TW data only; (2) Stationary photochemical box in TMS: similar to scenario 1 , monitoring station at TMS is assumed to be the center of the box model and the model is constrained only with TMS 
Table 1. Statistics of trace gases at the TMS and TW sites.

\begin{tabular}{lrrrr}
\hline \multirow{2}{*}{ Species } & \multicolumn{3}{c}{ TMS } & \multicolumn{2}{c}{ TW } \\
\cline { 2 - 5 } & Mean $\pm 95 \% \mathrm{CI}^{*}$ & Max Value & Mean $\pm 95 \% \mathrm{CI}^{*}$ & Max value \\
\hline $\mathrm{O}_{3}$ (ppbv) & $55 \pm 1$ & 163 & $22 \pm 1$ & 116 \\
$\mathrm{O}_{\mathrm{x}}$ (ppbv) & $58 \pm 1$ & 178 & $47 \pm 1$ & 157 \\
$\mathrm{NO}_{\mathrm{x}}$ (ppbv) & $10.7 \pm 0.3$ & 75 & $55 \pm 1$ & 262 \\
$\mathrm{CO}$ (ppbv) & $436 \pm 7$ & 842 & $517 \pm 8$ & 1150 \\
$\mathrm{SO}_{2}$ (ppbv) & $4.1 \pm 0.1$ & 28 & $6.1 \pm 0.2$ & 31 \\
\hline
\end{tabular}

${ }^{*}$ Mean $\pm 95 \%$ confidence intervals, ${ }^{1} \mathrm{O}_{\mathrm{x}}=\mathrm{NO}_{2}+\mathrm{O}_{3},{ }^{2} \mathrm{NO}_{\mathrm{x}}=\mathrm{NO}+\mathrm{NO}_{2}$

data; (3) Moving box (Mbox): this scenario is an oversimplified mountain-valley breezes phenomenon, with the grid located between TW and TMS monitoring stations and an air parcel moving in an idealized trajectory. During daytime hours (08:00-17:00 LT), the monitoring station in TW was assumed to be the center of the box model and the concentrations of the targeted species were homogenous throughout the box. The air parcel from TW followed the valley breeze entering the grid simultaneously, which brought trace gases emitted from TW to the top of the mountain. Photochemical reaction occurred under abundant sunlight at the top of the mountain (TMS). At this scenario, the model was constrained with TW data only. If mesoscale circulations were dominant, the modeled $\mathrm{O}_{3}$ levels compared well with the observations in TMS during daytime hours. When, at dusk, the air parcel was carried back down by the mountain breeze and into the grid until the next morning (18:00-07:00 LT), at this scenario, TMS was assumed to be the center of the box model and the model was constrained with TMS data only.

\section{Results and discussion}

\subsection{Overall observation results}

\subsubsection{Levels of trace gases and $\mathrm{O}_{3}$ episodes}

Table 1 summarizes the statistics of trace gases during the sampling period. In general, the mixing ratios of air pollutants were greater at TW than TMS, whereas the secondary pollutant $\mathrm{O}_{3}$ was greater at TMS than TW. The average concentrations of $\mathrm{NO}_{\mathrm{x}}, \mathrm{CO}$ and $\mathrm{SO}_{2}$ at TMS were $10.7 \pm 0.3 \mathrm{ppbv}, 436 \pm 7 \mathrm{ppbv}$ and $4.1 \pm 0.1 \mathrm{ppbv}$, which were $0.19,0.85$ and 0.67 times those measured at TW, respectively. On the other hand, the mean $\mathrm{O}_{3}$ concentration was $55 \pm 1 \mathrm{ppbv}$ at TMS, 2.5 times that of TW. To gain further information on the $\mathrm{O}_{3}$ pollution at the two sites, the frequency of $\mathrm{O}_{3}$ episode days was investigated. At the urban TW site, only one $\mathrm{O}_{3}$ episode day (19 September, concentration = $116 \mathrm{ppbv}$ ) and three near- $\mathrm{O}_{3}$ episode days (i.e., the peak hourly $\mathrm{O}_{3}$ mixing ratio between $80-100 \mathrm{ppbv}$, or China's Grade I standard) were observed. At the TMS site, the maximum hourly average $\mathrm{O}_{3}$ mixing ratio reached 163 ppbv.
Twenty-one $\mathrm{O}_{3}$ episode days (i.e., 8, 19-20 September; 2324, 29-31 October; and 1-3, 8-9, 11, 17-19, 22-23, 26-27 November) were found during the sampling period.

\subsubsection{Diurnal variation}

Figures $2 \mathrm{a}$ and $\mathrm{b}$ show the diurnal variations of mean $\mathrm{O}_{3}$, $\mathrm{NO}_{\mathrm{x}}, \mathrm{CO}, \mathrm{SO}_{2}$ and surface winds at TMS and TW, respectively. TMS and TW had similar diurnal patterns of $\mathrm{O}_{3}$, experiencing $\mathrm{O}_{3}$ maxima in the afternoon and minimum at night and in the morning. However, the maximum $\mathrm{O}_{3}$ at TMS showed a delay, when compared to that at TW. The average daily maximum $\mathrm{O}_{3}$ mixing ratio at TMS $(70 \pm 6 \mathrm{ppbv}$, 15:00 LT) appeared $1 \mathrm{~h}$ later $(p<0.05)$ than that observed at TW (35 \pm 4 ppbv, 14:00 LT). The delayed daily maximum $\mathrm{O}_{3}$ at TMS was due to the fact that the air mass arriving at TMS was generally more aged than that at TW, which may be attributed to regional transport (see Sect. Regional transport) and/or mesoscale circulations (see Sect. Mesoscale circulation). At TMS, $\mathrm{O}_{3}$ exhibited relatively stable concentrations from midnight to the early morning, a decrease at sunrise, a minimum at about 10:00 LT, a daytime buildup to a broad maximum value at about 15:00 LT, and a slow decrease until midnight, with an average diurnal difference of $16 \mathrm{ppbv}$. The slow nighttime decay of $\mathrm{O}_{3}$ at TMS might be attributed to the limited NO titration and the reduced boundary-layer mixing height. Indeed, the boundary-layer height was approximately $2 \mathrm{~km}$ in the daytime and reduced to about $1 \mathrm{~km}$ at night in Hong Kong (Guo et al., 2012).

The diurnal variations of $\mathrm{O}_{3}$ at TW had one peak at about 03:00 and another at 14:00 LT with a trough at about 07:00 LT (Fig. 2b). The peaks and the trough of $\mathrm{O}_{3}$ were corresponding to NO minimum and maximum, consistent with previous studies (Chan et al., 1998a; So and Wang, 2003). The combination of photochemical formation and downward mixing from the overlying air masses could result in the $\mathrm{O}_{3}$ daily peak in the afternoon (So and Wang, 2003; Guo et al., 2009). After reaching the daily peak (14:00 LT), $\mathrm{O}_{3}$ gradually decreased and approached the normal background level at night due to the fact that $\mathrm{NO}$ emitted during the rush hours could titrate some $\mathrm{O}_{3}$ and the photochemical production of $\mathrm{O}_{3}$ ceased at night (Chan et al., 1998a; So and Wang, 2003); 


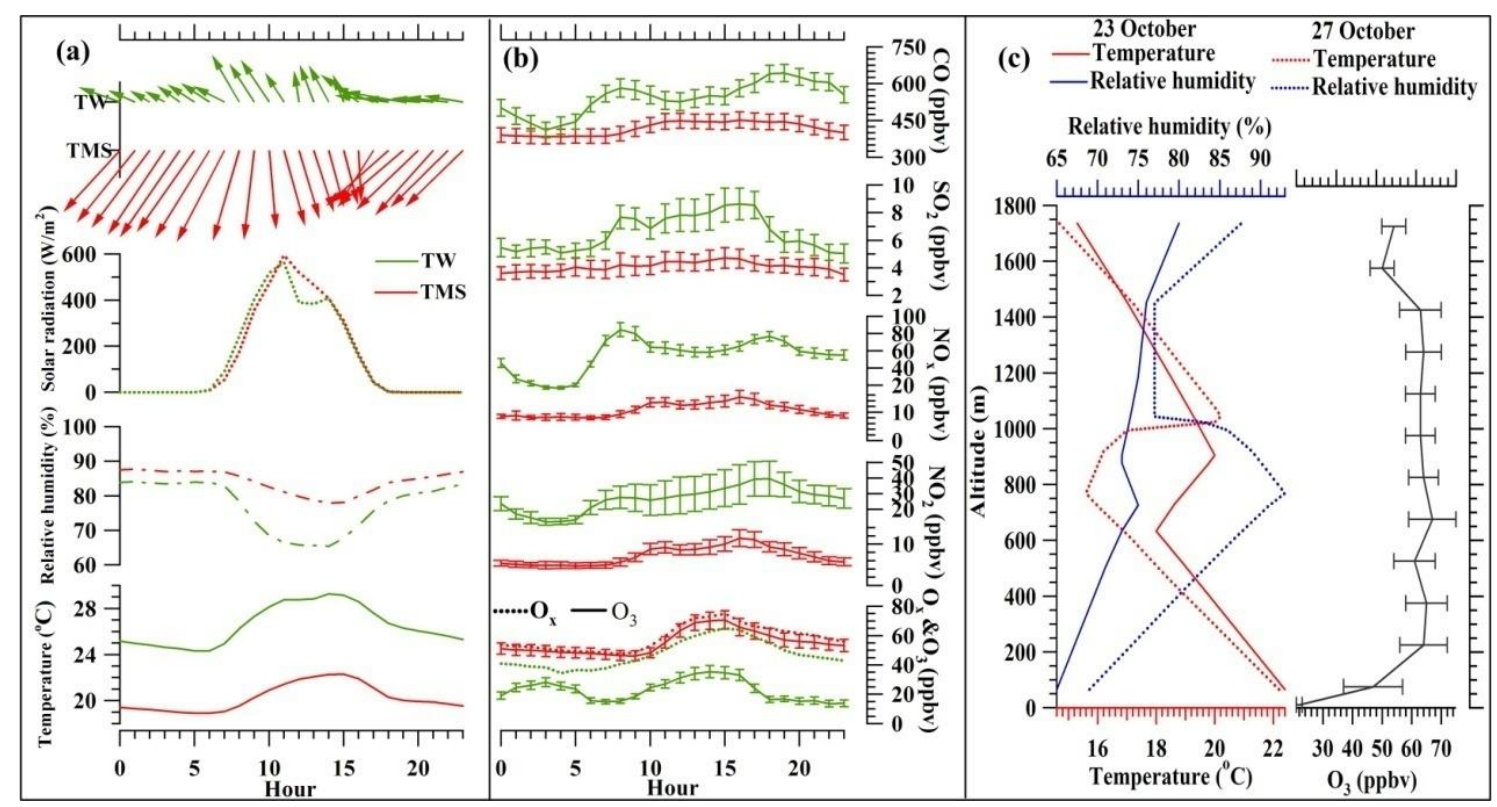

Fig. 2. (a) Surface meteorological conditions, (b) average diurnal patterns of trace gases at TMS and TW and (c) vertical profiles of meteorological conditions and $\mathrm{O}_{3}$ in Hong Kong.

and to a lesser extent, the dry deposition process could also cause the drop of $\mathrm{O}_{3}$ concentration (Zanis et al., 2007; Xue et al., 2011). Then, $\mathrm{O}_{3}$ started to buildup slowly and presented a peak in the early morning, which was more obvious when a trough was generated at 07:00 LT. This trough was caused by the NO from the fresh vehicular emission which titrated part of the $\mathrm{O}_{3}$ (Chan et al., 1998a; So and Wang et al., 2003). On the other hand, the small $\mathrm{O}_{3}$ peak in the early morning may be caused by the decreased titration of NO. While NO started to decrease at 00:00 LT and reached its lowest level at about 04:00 LT (data not shown), $\mathrm{O}_{3}$ increased gradually and formed a peak from 00:00-05:00 LT. In addition, the small $\mathrm{O}_{3}$ peak in the early morning might be also attributed to the constant transport of $\mathrm{O}_{3}$ to TW by southeasterly flows from the South China Sea where $\mathrm{O}_{3}$ was less consumed (So and Wang et al., 2003; Guo et al., 2009). This speculation was based on the fact that the winds changed from easterly to southeasterly from midnight until dawn. The imposed $\mathrm{O}_{3}$ from the South China Sea and the minimum traffic activities caused higher $\mathrm{O}_{3}$ concentrations in the early morning than the normal background level at night (So and Wang, 2003; Guo et al., 2009). The speculation was further evidenced by the diurnal variations of dimethyl sulfide (DMS), an ocean tracer. DMS had a small peak observed from 00:00 to 03:00 LT (data not shown), corresponding to the small $\mathrm{O}_{3}$ peak observed between midnight and dawn. Previous studies indeed reported that southeasterly winds from the South China Sea could result in higher $\mathrm{O}_{3}$ levels at night (So and Wang, 2003; Guo et al., 2009).

The diurnal variation of $\mathrm{NO}_{\mathrm{x}}$ at the TW site showed a typical urban profile, i.e., bimodal structure. The first peak appeared in the early morning (07:00-09:00 LT) while the second peak was at about 18:00-19:00 LT, coincident with the traffic pattern of Hong Kong. On the other hand, a broad $\mathrm{NO}_{\mathrm{x}}$ peak with a delay (compared to TW) was observed at TMS. The peak $\mathrm{NO}_{\mathrm{x}}$ value $(15.3 \pm 2.2 \mathrm{ppbv})$ at TMS was much lower $(p<0.01)$ than that at TW $(84.5 \pm 8.1 \mathrm{ppbv})$. In addition, the diurnal profiles of $\mathrm{SO}_{2}$ and $\mathrm{CO}$ were similar at TMS, with a small and broad peak in the afternoon, which might be indicative of the influence of regional transport (Guo et al., 2009; Jiang et al., 2010) and/or mesoscale circulations (Parrish et al., 1993; Gao et al., 2005; Wang et al., 2006).

\subsection{Which factors are responsible for the discrepancy of $\mathrm{O}_{3}$ pollution observed at TMS and TW?}

While comparable solar radiation was found at the two sites ( $p>0.1$, with the average value of $275 \pm 114$ and $270 \pm$ $105 \mathrm{~W} \mathrm{~m}^{-2}$ at TMS and TW, respectively), higher temperature, lower relative humidity and wind speed, which are conducive for photochemical $\mathrm{O}_{3}$ formation (Wang et al., 2003; Jiang et al., 2008; Guo et al., 2009), were found at the urban TW site (Fig. 2a, b). Nonetheless, the $\mathrm{O}_{3}$ concentrations at TW were much lower than TMS. The difference of the mean $\mathrm{O}_{3}$ levels between the two sites during the sampling period was 33 ppbv (Table 1), while hourly differences reached up to $122 \mathrm{ppbv}$. As the two sites are separated by a distance of about $7 \mathrm{~km}$ and an elevation of $630 \mathrm{~m}$, the factors that could cause the discrepancy of $\mathrm{O}_{3}$ levels observed at the two sites are discussed in the following sections. 

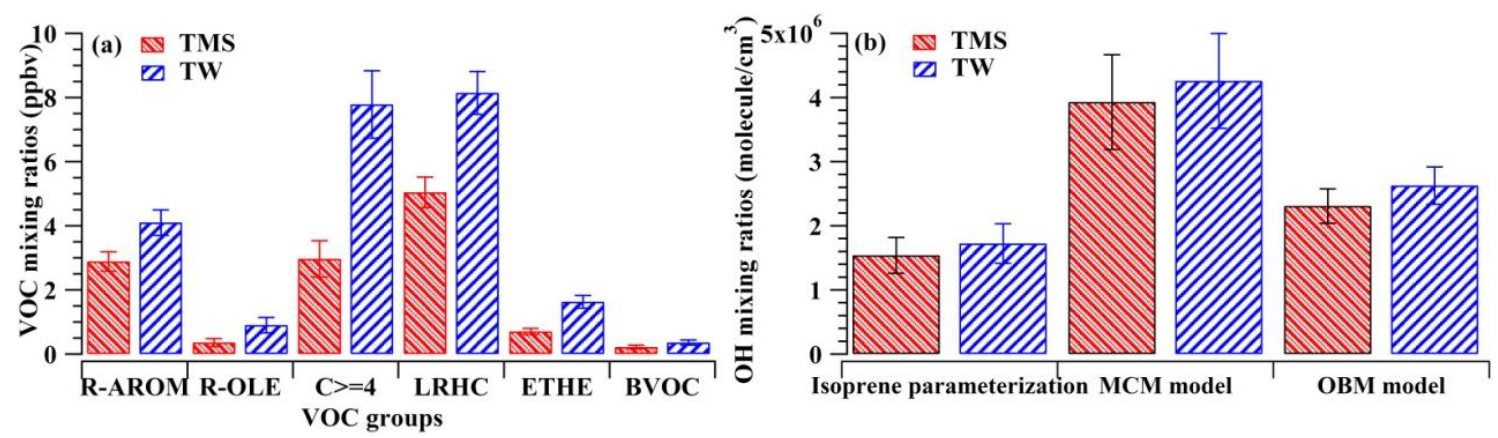

Fig. 3. The mean mixing ratios of (a) different VOC species and (b) OH radical at TMS and TW during the sampling period. Vertical bars are $95 \%$ confidence intervals.

\subsubsection{Degree of photochemical reactions}

Comparing the levels of precursors is a useful tool to investigate the degree of photochemical reactions at two different sites (Sillman, 1999; Jenkin and Clemitshaw, 2000). Figure $3 \mathrm{a}$ shows the mean mixing ratios of different VOC groups at the two sites. The VOC species were classified into six functional types, i.e., R-AROM group (reactive aromatics; including xylenes, toluene, trimethylbenzenes and ethylbenzene), R-OLE (reactive olefins; comprising all olefins except ethene), $\mathrm{C} \geq 4$ (including alkanes with four or more carbons), LRHC (low reactive hydrocarbon carbons; comprising ethane, propane, ethyne and benzene), ETHE (ethene) and BVOC (including isoprene, $\alpha / \beta$-pinene and limonene). During the sampling period, the VOC levels were considerably lower at TMS than TW $(p<0.01)$, which is consistent with other $\mathrm{O}_{3}$ precursors, i.e., $\mathrm{NO}_{\mathrm{x}}$ and $\mathrm{CO}$ (Table 1).

On the other hand, the levels of hydroxyl radical $(\mathrm{OH}$ radical) were further compared at the two sites. As we did not measure $\mathrm{OH}$ radical in situ, its mixing ratio during daytime hours (07:00-19:00 LT) was calculated using two models, i.e., an observation based model (OBM) and a Master Chemical Mechanism (MCM) model. The detailed description of the OBM model can be found elsewhere (Zhang et al., 2007, 2008; Cheng et al., 2010; Ling et al., 2011). Besides simulation results, the concentration of $\mathrm{OH}$ radical was also estimated from the parameterization method through the empirical relationship between isoprene (ISOP) and its oxidation products, i.e., methacrolein (MAC) and methyl vinyl ketone (MVK), based on the assumption that the processing time of the air mass was identical for MAC and MVK and there were no additional sources of MAC and MVK apart from the oxidation of isoprene (Eqs. 1-5 as follows),

$$
\begin{aligned}
& \mathrm{ISOP}+\mathrm{OH} \rightarrow 0.63 \mathrm{HCHO}+0.32 \mathrm{MVK} \\
& \quad+0.23 \mathrm{MAC} k_{1}=1.0 \times 10^{-10} \mathrm{~cm}^{-3} \mathrm{~s}^{-1}, \\
& \mathrm{MAC}+\mathrm{OH} \rightarrow \text { products } k_{2}=3.3 \times 10^{-11} \mathrm{~cm}^{-3} \mathrm{~s}^{-1}, \\
& \mathrm{MVK}+\mathrm{OH} \rightarrow \text { products } k_{3}=1.9 \times 10^{-11} \mathrm{~cm}^{-3} \mathrm{~s}^{-1},
\end{aligned}
$$

$\frac{[\mathrm{MAC}]}{[\mathrm{ISOP}]}=\frac{0.23 k_{1}}{\left(k_{2}-k_{1}\right)}\left(1-e^{\left(k_{1}-k_{2}\right)[\mathrm{OH}]_{\text {avg }} t}\right)$

$\frac{[\mathrm{MVK}]}{[\mathrm{ISOP}]}=\frac{0.32 k_{1}}{\left(k_{3}-k_{1}\right)}\left(1-e^{\left(k_{1}-k_{3}\right)[\mathrm{OH}]_{\text {avg }} t}\right)$,

where [MAC], [ISOP] and [MVK] were the measured values for MAC, isoprene and MVK, respectively, and $t$ is the processing time. Details of this method can be found in Liu et al. (2009) and Yuan et al. (2012). Figure $3 \mathrm{~b}$ presents the calculated and simulated $\mathrm{OH}$ radical concentrations at TMS and TW during daytime hours. At TMS, the average mixing ratios of $\mathrm{OH}$ radical simulated by OBM and MCM models were $(2.31 \pm 0.27) \times 10^{6}$ and $(3.93 \pm 0.74) \times 10^{6}$ molecule $\mathrm{cm}^{-3}$, respectively, and $(2.03 \pm 0.28) \times 10^{6}$ molecule $\mathrm{cm}^{-3}$ from the calculations of the parameterization method. On the other hand, the average concentration of $\mathrm{OH}$ at TW calculated by the corresponding three methods were $(2.63 \pm 0.29) \times 10^{6},(4.26 \pm 0.74)$ $\times 10^{6}$ and $(2.27 \pm 0.31) \times 10^{6}$ molecule $\mathrm{cm}^{-3}$, respectively. Though variations were found for the results of different methods, the average mixing ratios of $\mathrm{OH}$ radical at the two sites were comparable $(p>0.05)$. In addition, by considering the factor of fractional conversion, which represented the relative importance of photolysis reactions on $\mathrm{OH}$ radical formation in the atmosphere (Atkinson, 1997; Jenkin and Clemitshaw, 2000), the mean fraction conversion index at TMS $(0.17 \pm 0.03)$ was lower than that at TW $(0.23 \pm 0.04$, $p<0.05)$. Based on the aforementioned analyses, it could be concluded that photochemical reactions at TMS were not stronger than at TW. Hence, the higher $\mathrm{O}_{3}$ levels observed at TMS than those at TW were not induced by the different degrees of photochemical reactions.

\subsubsection{Influence of NO titration}

The feature of higher $\mathrm{O}_{3}$ at the higher elevation site (TMS) than at the ground-level site (TW) is somewhat in line with the vertical profiles of $\mathrm{O}_{3}$ observed in Hong Kong and other 

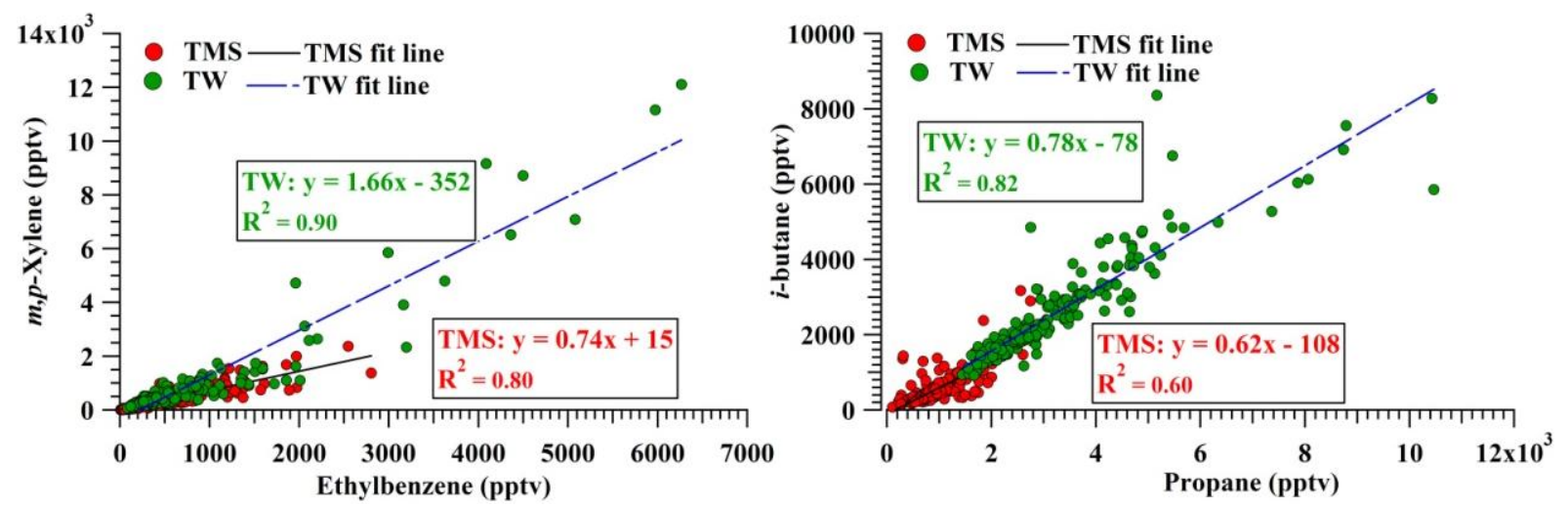

Fig. 4. The scatter plots of (a) $m, p$-xylene vs. ethylbenzene and (b) $i$-butane vs. propane at TMS and TW.

locations (e.g., Wang et al., 2001; Chen et al., 2002; Tseng et al., 2009; Ma et al., 2011). Wang et al. (2001) showed that $\mathrm{O}_{3}$ generally increased with elevation above surface and had a modest peak between 550 and $650 \mathrm{~m}$ at the subtropical Cape D' Aguilar site in Hong Kong in October and November 2001. In addition, Chen et al. (2002) and Tseng et al. (2009) reported that high $\mathrm{O}_{3}$ concentrations appeared at the height of 500-600 $\mathrm{m}$ and decreased rapidly towards the ground during daytime in central Taiwan. Both studies suggested that high $\mathrm{O}_{3}$ concentrations in the higher elevations were partially attributed to the limited NO titrations, due to the lower levels of NO at higher elevations. In this study, the average NO mixing ratio at the mountain site (TMS) was $3.5 \pm 0.1 \mathrm{ppbv}$, compared to $28 \pm 1 \mathrm{ppbv}$ at $\mathrm{TW}$, indicating that the higher $\mathrm{O}_{3}$ mixing ratios at TMS were likely attributed to the limited NO titration $\left(\mathrm{O}_{3}+\mathrm{NO}=\mathrm{NO}_{2}+\mathrm{O}_{2}\right)$. The $\mathrm{NO}$ titration is a main process of loss for $\mathrm{O}_{3}$, which can convert $\mathrm{NO}$ to $\mathrm{NO}_{2}$ rapidly (Tang et al., 2012). In order to investigate the titration effect, the concentrations of "oxidant" $\mathrm{O}_{\mathrm{x}}$ (the sum concentration of $\mathrm{O}_{3}+\mathrm{NO}_{2}$ ) were calculated at the two sites (Jenkin and Clemitshaw, 2000; Chen et al., 2002; Jiang et al., 2010). The mean $\mathrm{O}_{\mathrm{x}}$ mixing ratio was $47 \pm 1 \mathrm{ppbv}$ at $\mathrm{TW}$, close to the value ( $58 \pm 1 \mathrm{ppbv}$ ) found at TMS (Table 1), confirming lower degree of NO titration at the TMS site.

\subsubsection{Influence of vertical meteorological conditions}

Besides NO titration, vertical structure of meteorological variables is an important factor that could influence the $\mathrm{O}_{3}$ levels at different elevations (Lin et al., 2007; Ma et al., 2011). Therefore, we investigated the vertical profiles of meteorological conditions, such as temperature and relative humidity in Hong Kong on the selected 40 days, including twenty-one (21) $\mathrm{O}_{3}$ episode days and selected nineteen (19) non- $\mathrm{O}_{3}$ episode days before/after the $\mathrm{O}_{3}$ episode days. Two cases (23 and 27 October) are presented here as examples (Fig. 2c). The vertical profile of meteorological data for Hong Kong was downloaded from the Department of Atmospheric Science, College of Engineering,
University of Wyoming (http://weather.uwyo.edu/upperair/ sounding.html). In addition, the vertical profile of $\mathrm{O}_{3}$ was the average pattern of the data in 2005-2010, which was obtained from the Measurement of Ozone by Airbus In-Service Aircraft project (MOZAIC, http://mozaic.aero.obs-mip.fr/ web/). Detailed description for this dataset could be found in Ding et al. (2008). It should be noted that the vertical meteorological data presented here were obtained from the King's Park station (site $45004,22.32^{\circ} \mathrm{N}, 114.17^{\circ} \mathrm{E}$, with straight line distances of $12 \mathrm{~km}$ and $7 \mathrm{~km}$ to TMS and TW, respectively), at 08:00 LT. Inspection of the figures suggested that fluctuation in relative humidity and potential temperature caused by inversion layers was found at the altitudes of 600$900 \mathrm{~m}$ on 23 October and $720-1000 \mathrm{~m}$ on 27 October. Furthermore, the modified bulk Richardson number $(R i)$ (Doran et al., 2003) was calculated, and the $R i$ values were 4.6 and 1.0 at the altitudes from 600 to $900 \mathrm{~m}$ on 23 October and from 720 to $1000 \mathrm{~m}$ on 27 October, respectively, indicating that the atmosphere was stable and no wind-shear turbulence existed at those elevations (Lin et al., 2007). These inversion layers suppressed dispersion of air pollutants and gave rise to high $\mathrm{O}_{3}$ levels at high altitudes, consistent with previous studies (Lin et al., 2007; Ma et al., 2011). Indeed, the inversion layer was often ( 24 days of the selected 40 days) observed at the range of altitudes of 500 to $1000 \mathrm{~m}$, which may be a factor that resulted in the high $\mathrm{O}_{3}$ levels at the TMS site located at the elevation of $640 \mathrm{~m}$.

\subsubsection{Influence of atmospheric processes}

Figure 4 presents the scatter plots of (a) $m, p$-xylene to ethylbenzene and (b) $i$-butane to propane at TMS and TW. Since $m, p$-xylene and $i$-butane are more reactive than ethylbenzene and propane, respectively, the ratios of $m, p$-xylene/ethylbenzene and $i$-butane/propane will decrease when photochemical reaction occurs during the air mass transport. These two pairs of ratios were much lower at TMS $(p<0.05)$, with the $m, p$-xylene/ethylbenzene ratio of $0.74 \pm 0.04 \mathrm{pptv}_{\mathrm{pptv}}{ }^{-1}$ 

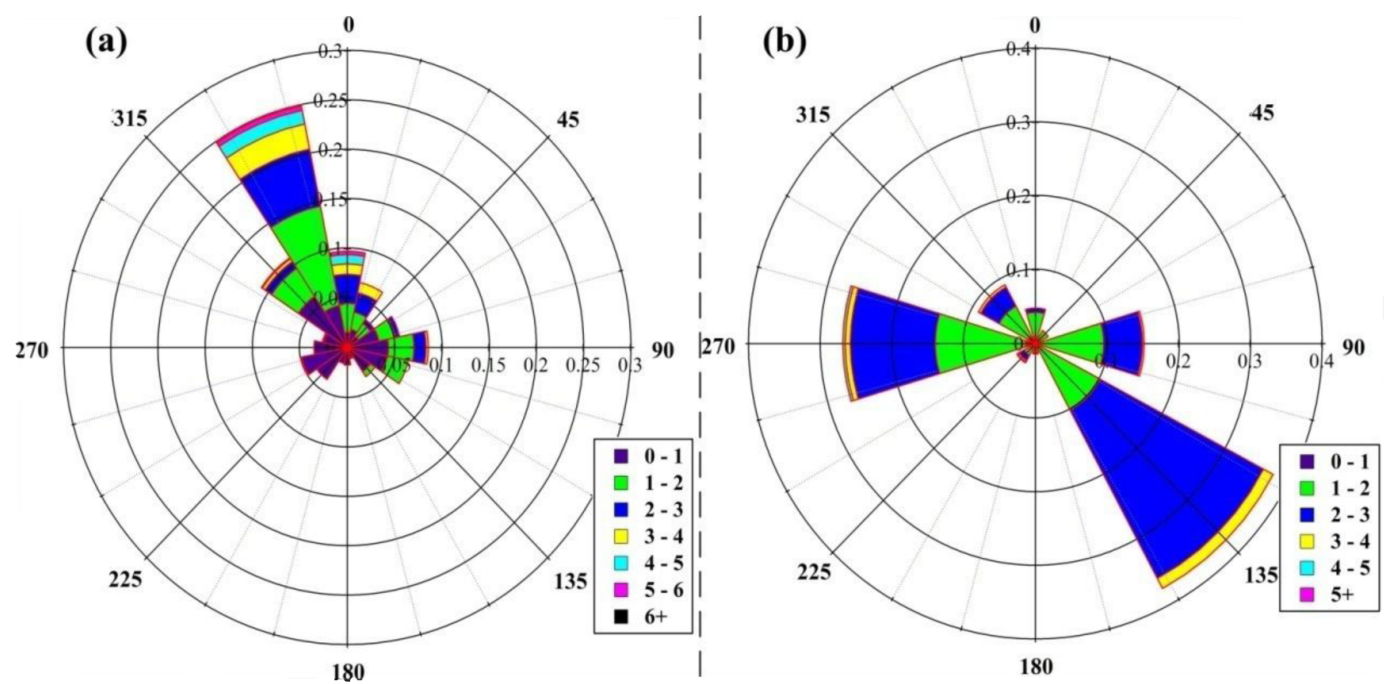

Fig. 5. Combined wind rose maps at daytime hours during the sampling period at (a) TMS and (b) TW.

$(1.66 \pm 0.05$ at TW) and the $i$-butane/propane ratio of $0.62 \pm 0.06$ pptv pptv $^{-1}(0.78 \pm 0.02$ at TW $)$. In addition, the ratio of alkyl nitrates to their parent hydrocarbons was also investigated. Since the lifetime of ethyl nitrate is shorter than ethane, and the lifetime of 2-butyl nitrate is longer than $n$ butane, the more aged air mass will have a smaller ratio of ethyl nitrate/ethane vs. 2-butyl nitrate/ $n$-butane (Roberts et al., 1998; Reeves et al., 2007). The ratio of ethyl nitrate/ethane vs. 2-butyl nitrate $/ n$-butane was $0.17 \pm 0.01$ at TMS, while it was $0.91 \pm 0.10$ at TW. The results suggested that the air mass arriving at TMS was generally more aged than that at TW, which may be attributed to regional transport (Guo et al., 2009; Cheng et al., 2010) and/or mesoscale circulations, i.e., mountain-valley breezes.

\section{Regional transport}

Different wind fields were observed at TMS and TW, indicating the influence of different air masses. The combined wind roses (Fig. 5) during the sampling period clearly demonstrated that the dominated surface wind at TMS was generally from the north with the dominant wind speeds between 0.02 and $4 \mathrm{~m} \mathrm{~s}^{-1}$, whereas the prevailing winds were generally from the southeast with dominnt wind speeds of 1$3 \mathrm{~m} \mathrm{~s}^{-1}$ at TW. Moreover, the diurnal wind patterns showed a clear shift in wind direction at TW, from easterly winds at night and early morning to stronger southerly winds in the afternoon (Fig. 2a, b). On the other hand, the winds at TMS were generally from the north, with increased speeds at night and in the early morning, and decreased speeds during daytime hours. The two different wind patterns indicated that $\mathrm{O}_{3}$ mixing ratios at TMS and TW may be influenced by different air flows. Previous studies (So and Wang, 2003; Wang and Kwok, 2003; Guo et al., 2009) have reported that ratios of $\mathrm{SO}_{2} / \mathrm{NO}_{\mathrm{x}}$ and $\mathrm{CO} / \mathrm{NO}_{\mathrm{x}}$ were lower in Hong Kong than in the PRD due to the use of low-sulfur-containing fuel and more efficient combustion technology in Hong Kong. In this study, the ratios of $\mathrm{SO}_{2} / \mathrm{NO}_{\mathrm{x}}$ and $\mathrm{CO} / \mathrm{NO}_{\mathrm{x}}$ were $0.13 \pm 0.04$ and $12.85 \pm 0.37 \mathrm{ppbv} \mathrm{ppvv}^{-1}$ at TW, within the ranges of 0.02-0.19 and 5.21-19.25 ppbv ppbv ${ }^{-1}$ from September to November 2010 observed in Hong Kong urban air (data from HKEPD, http://www.epd.gov.hk), respectively. This suggested that air masses at TW were mainly influenced by Hong Kong local emissions. On the other hand, the ratios of $\mathrm{SO}_{2} / \mathrm{NO}_{\mathrm{x}}$ and $\mathrm{CO} / \mathrm{NO}_{\mathrm{x}}$ were much higher at TMS, with the values of $0.40 \pm 0.01$ and $46.38 \pm 0.71 \mathrm{ppbv} \mathrm{ppv}^{-1}$, respectively, which were within the values reported in the PRD region (0.4-1.26 and 11.9-52.0, respectively) (Wang et al., 2005; Guo et al., 2009; Zhao et al., 2011). Hence, the relatively higher ratios of $\mathrm{SO}_{2} / \mathrm{NO}_{\mathrm{x}}$ and $\mathrm{CO} / \mathrm{NO}_{\mathrm{x}}$ at TMS indicated the possible influence of PRD emissions.

The urban centers in the PRD region of China, located at straight line distances of $15-184 \mathrm{~km}$ north of the TMS site, are sources of air pollutants, including $\mathrm{O}_{3}$ and its precursors (Chan and Chan, 2000; Huang et al., 2006; Guo et al., 2009). At high wind speed $\left(>2 \mathrm{~m} \mathrm{~s}^{-1}\right)$, interregional transport of air pollutants generated from the PRD region could arrive in Hong Kong in several hours, thereby increasing the levels of $\mathrm{O}_{3}$ and its precursors (Wang et al., 2005, 2009; Huang et al., 2006; Zhang et al., 2007; HKEPD, 2012). To investigate the effect of regional transport from the PRD region on the air pollutants at the TMS site, we first examined the levels of air pollutants under the influence of regional transport (scenario 1), i.e., northerly winds $\left(270^{\circ}<\right.$ wind direction $\leq 360^{\circ}$ and $0^{\circ} \leq$ wind direction $\left.<90^{\circ}\right)$ with high speed $\left(>2 \mathrm{~m} \mathrm{~s}^{-1}\right)$ and local emissions (scenario 2$)$, i.e., southerly and easterly winds $\left(90^{\circ} \leq\right.$ wind direction $\leq 270^{\circ}$ ) and northerly winds with low speed $\left(<2 \mathrm{~m} \mathrm{~s}^{-1}\right), \mathrm{O}_{3}, \mathrm{CO}, \mathrm{SO}_{2}$ and TVOCs showed 
Table 2. Comparison of VOC ratios for TMS regional air, urban Hong Kong and PRD region.

\begin{tabular}{lcccc}
\hline Site & $\begin{array}{c}\text { TMS regional } \\
\text { air }^{\text {a }}\end{array}$ & $\begin{array}{c}\text { TW urban } \\
\text { air }^{\mathrm{a}}\end{array}$ & $\begin{array}{c}\text { Other Hong Kong } \\
\text { urban air }^{\mathrm{b}}\end{array}$ & PRD region $^{\mathrm{c}}$ \\
\hline Ethyne/propane & 1.46 & 0.89 & 0.99 & $0.73-1.89$ \\
Benzene/propane & 0.57 & 0.25 & 0.29 & $0.35-0.70$ \\
Toluene/benzene & 3.14 & 5.13 & 4.11 & $1.75-5.40$ \\
$n$-Butane/propane & 0.62 & 1.22 & 0.93 & $0.47-0.52$ \\
\hline
\end{tabular}

${ }^{\mathrm{a}}$ This study; ${ }^{\mathrm{b}}$ HKEPD (2010); ${ }^{\mathrm{c}}$ data from Barletta et al. (2008) and Zhang et al. (2012).

higher mixing ratios $(p<0.05)$ in scenario 1 , with average values of $57 \pm 2 \mathrm{ppbv}, 495 \pm 9 \mathrm{ppbv}, 4.6 \pm 0.2 \mathrm{ppbv}$ and $47 \pm 7 \mathrm{ppbC}$, respectively, while the respective average concentrations were $48 \pm 2 \mathrm{ppbv}, 370 \pm 11 \mathrm{ppbv}, 3.6 \pm 0.2 \mathrm{ppbv}$ and $33 \pm 7 \mathrm{ppbC}$ for scenario 2 . This feature was consistent with previous studies (Chan and Chan, 2000; Guo et al., 2009). In addition, the relationship between VOC variability and the atmospheric lifetime was analyzed to estimate the distance of the sources of air pollutants with/without the influence of regional transport (Jobson et al., 1998; Warneke and de Gouw, 2001; Wang et al., 2005). This relationship is expressed as follows:

$S_{\operatorname{lnx}}=A \tau^{-b}$,

where $S_{\operatorname{lnx}}$ is the standard deviation of the natural logarithm of the mixing ratio $X, \tau$ is the atmospheric lifetime, and $A$ and $b$ are fit parameters. The detailed description for this function can be referred to in Wang et al. (2005). In brief, the constant $b$ is related to the source-receptor distances and lies between 0 and 1 . The closer the sampling site is from the air pollutant sources, the smaller the exponent $b$ (Ehhalt et al., 1998; Wang et al., 2005). Figure 6 presents the relationship of variability with lifetime for different VOC species under the influence of scenarios 1 and 2. It can be found that the $b$ exponent was higher in scenario 1 than in scenario $2(p<0.05)$, indicating that air masses at TMS were more frequently impacted by regional transport, particularly under prevailing northerly winds with high speeds (Wang et al., 2005).

Therefore, to further assess the possible influence of PRD air masses on the air quality at TMS, ambient concentration ratios of VOCs i.e., ethyne/propane, benzene/propane, toluene/benzene and $n$-butane/propane were compared among the TMS samples affected by regional transport, the Hong Kong urban air samples and samples collected in the PRD region (Table 2). Compared to those in Hong Kong urban areas, higher ratios of ethyne/propane and benzene/propane were found in the PRD region due to the high combustion emissions and solvent usage (Barletta et al., 2008; HKEPD, 2010; Zhang et al., 2012). On the other hand, $n$-butane and propane are generally liquefied petroleum gas (LPG) tracers. The ratio of $n$-butane/propane was lower in the PRD than that in Hong Kong urban areas because of

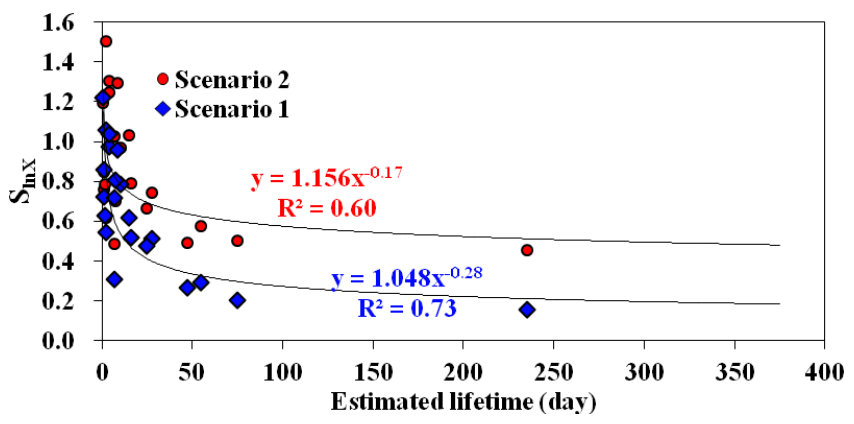

Fig. 6. The correlation of variability with lifetime for different VOC species with/without the influence of regional transport.

the high percentage of $n$-butane in the composition of LPG used in Hong Kong (Tsai et al., 2006; Tang et al., 2008; Ho et al., 2009; Zhang et al., 2012). Moreover, a higher ratio of toluene/benzene was found in Hong Kong urban air as toluene was a distinct emission from Hong Kong due to the high toluene content in unleaded gasoline (So and Wang et al., 2003; Ho et al., 2004, 2009). In this study, for the TMS samples affected by regional air masses, the above four ratios were between the values observed in Hong Kong urban air and the PRD region. These results confirmed that the air pollutants at TMS were somewhat influenced by air masses from the highly polluted PRD region, apart from the influence of Hong Kong urban air by mesoscale circulations (discussed in Sect. Mesoscale circulation).

\section{Mesoscale circulation}

To investigate the influence of mountain-valley breezes on air mass transport during this study, correlations of $\mathrm{SO}_{2}$ and $\mathrm{CO}$ at the TMS and TW sites were analyzed. Figures $7 \mathrm{a}$ and $\mathrm{b}$ show correlations of daytime and nighttime averages of $\mathrm{CO}$ and $\mathrm{SO}_{2}$ for TMS vs. TW. In general, good to moderate correlations were found for both $\mathrm{CO}\left(R^{2}=0.73\right.$ and 0.63 for daytime and nighttime hours, respectively) and $\mathrm{SO}_{2}$ $\left(R^{2}=0.62\right.$ and 0.69 for daytime and nighttime hours, respectively) between the two sites, suggesting some interplays of air masses. The slopes, which were less than one, implied the dilution of air masses during their transport from TW to TMS. Note that the prevailing winds at the mountain site 

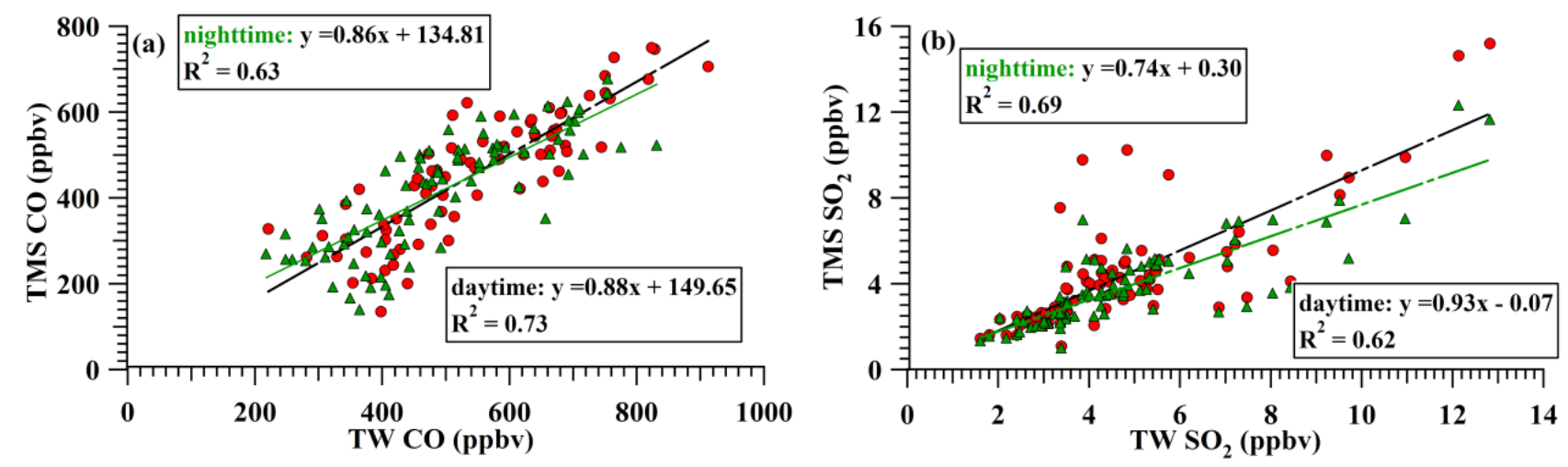

Fig. 7. Scatter plots of (a) $\mathrm{CO}$ and (b) $\mathrm{SO}_{2}$ during daytime and nighttime hours between TMS and TW.

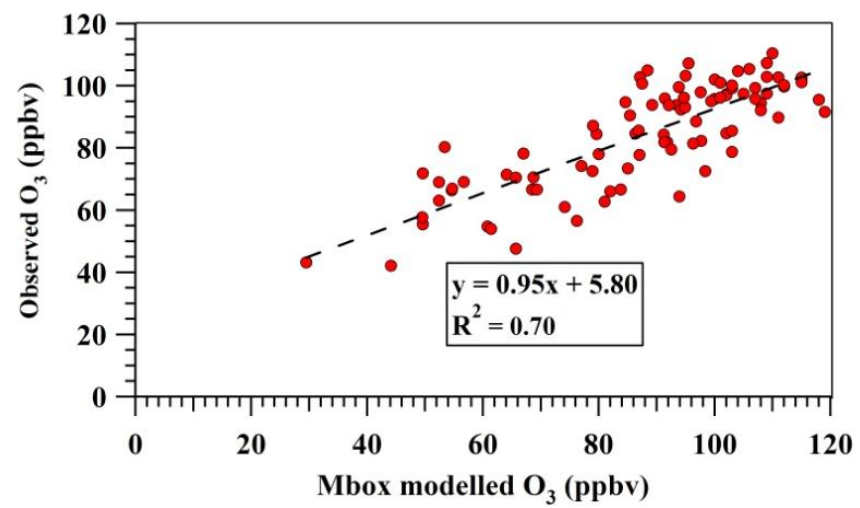

Fig. 8. The correlation between the observed data and the MCM modeled results during daytime hours.

were mainly from the north while those at TW were mostly from the southeast (Fig. 2a). It is unlikely that the correlations for TMS vs. TW were caused by the same regional air mass. Therefore, it suggested that the interplays of air masses and the moderate to good correlations between the two sites were likely caused by the influence of mesoscale circulations, i.e., mountain-valley breezes. The lower correlation for $\mathrm{CO}$ observed during the nighttime hours was likely due to the fact that the observed CO concentrations at TW were higher because of the local urban emissions. The lower correlation for $\mathrm{SO}_{2}$ during daytime hours was driven by a few data points with higher observed than predicted $\mathrm{SO}_{2}$ levels at TMS. This is mostly attributed to the influence of regional transport (Sect. 3.2.4), which could bring the air pollutants from the PRD region to TMS (Fig. 7b).

The correlation between the observation and the results of the moving box (Mbox) model for TMS and TW developed by the PBM-MCM was also explored to evaluate the influence of mesoscale circulation. Since photochemical $\mathrm{O}_{3}$ formation occurs during daytime hours, the photochemical processes between 08:00 and 17:00 LT were simulated using the Mbox model on the selected VOC sampling days, i.e., 24, 29-31 October, 1-3, 9 and 19 November 2010, when the potential influence of mesoscale circulations was dominant (Fig. 9). In addition, to determine whether regional transport had influence on the air pollutants for the modeling periods as stated above, wind speeds, ratios of $\mathrm{SO}_{2} / \mathrm{NO}_{\mathrm{x}}$, $\mathrm{CO} / \mathrm{NO}_{\mathrm{x}}$, and toluene/benzene during daytime hours (08:0017:00 LT) at TMS were compared with those influenced by the regional transport (in Sect. Regional transport). If the mesoscale circulations were dominant during the Mbox modeling periods, lower wind speeds, lower ratios of $\mathrm{SO}_{2} / \mathrm{NO}_{\mathrm{x}}$ and $\mathrm{CO} / \mathrm{NO}_{\mathrm{x}}$ and a higher ratio of toluene/benzene would be observed when compared to those observed for the period influenced by regional transport (Sect. Regional transport). Indeed, the wind speed, ratios of $\mathrm{SO}_{2} / \mathrm{NO}_{\mathrm{x}}$ and $\mathrm{CO} / \mathrm{NO}_{\mathrm{x}}$ during the mesoscale modeling period were $1.57 \pm 0.16 \mathrm{~m} \mathrm{~s}^{-1}$, $0.37 \pm 0.02$ and $42.01 \pm 1.08 \mathrm{ppbv} \mathrm{ppv}^{-1}$, respectively, which were much lower $(p<0.05)$ than those observed in the period influenced by regional transport at TMS, with values of $2.93 \pm 0.07 \mathrm{~m} \mathrm{~s}^{-1}, 0.45 \pm 0.02$ and $51.01 \pm 1.28 \mathrm{ppbv} \mathrm{ppbv}^{-1}$, respectively. Moreover, the ratio of toluene/benzene $\left(4.01 \pm 0.28 \mathrm{pptv} p p t v^{-1}\right)$ was much higher $(p<0.05)$ during the selected days for MBox modeling than that $(3.14 \pm 0.38)$ in the periods affected by regional transport, confirming that mesoscale circulations were dominant for the modeling periods. Figure 8 shows the correlation between observed and modeled $\mathrm{O}_{3}$ during daytime hours. The time lag between the two sites was evaluated from dividing the distance between TMS and TW by the average value of the observed wind speed during daytime hours. The value of time lag was factored in for pairs of data points used for correlation analysis, i.e., a sample collected at 09:00 LT at TW corresponded to a sample at 10:00 LT at TMS for a valley breeze during daytime hours if the time difference was one hour. Good correlation $\left(R^{2}=0.70\right)$ between Mbox modeled and observed $\mathrm{O}_{3}$ was found during daytime hours (Fig. 8), suggesting that $\mathrm{O}_{3}$ at TMS was related to the air pollutants at TW. This further indicated the influence of mesoscale circulations. 

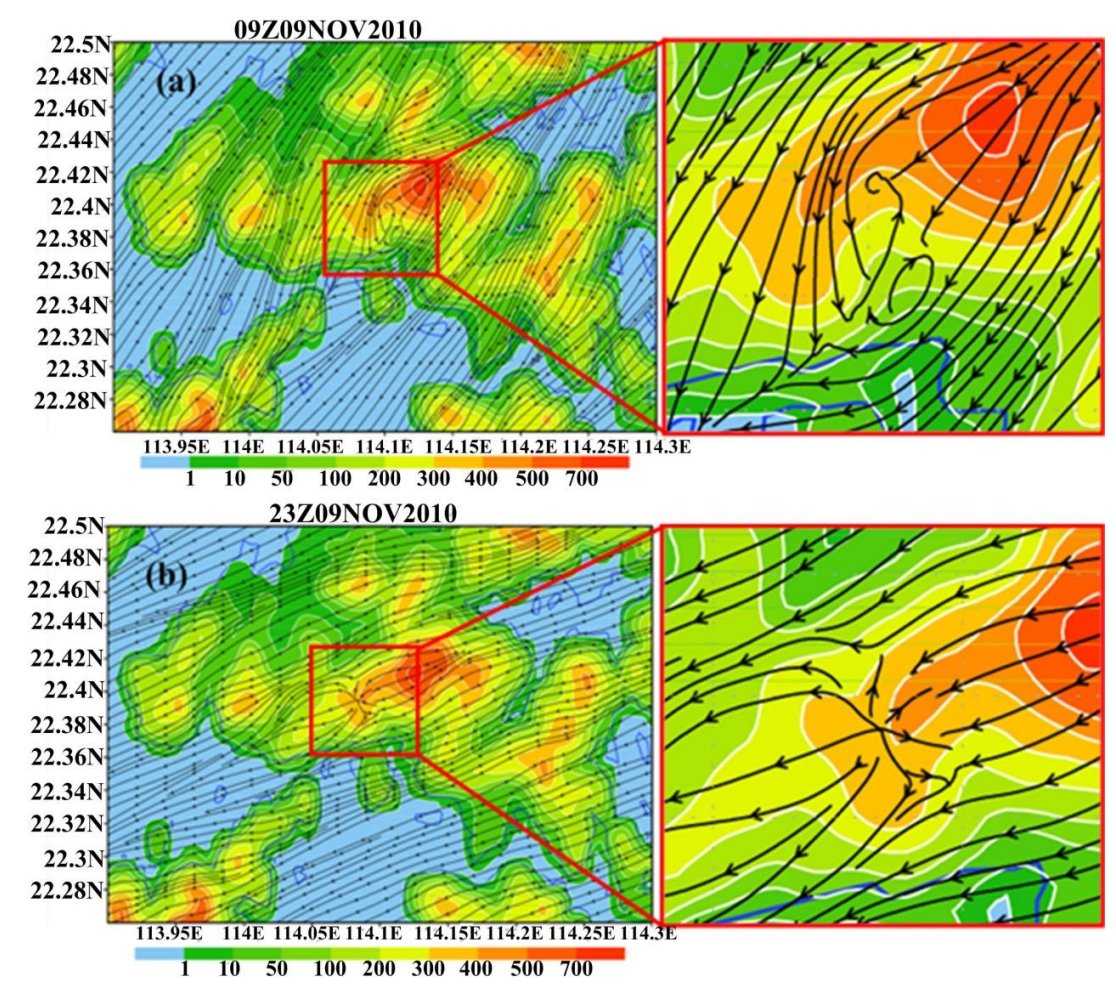

Fig. 9. Simulation of mountain-valley breezes on 9 November 2010: (a) valley breezes at daytime; (b) mountain breezes at nighttime.

In addition to the above analysis, mountain-valley breezes were simulated using a domain system of five nested grids (Sect. 2.3). The modeling focused on 16-18, 23 September, 23-24, 29-31 October, 1-3, 9, 12, and 19 November 2010, when evidence for the mesoscale circulation was clear based on the meteorological data and the levels of air pollutants. Here, the simulation results for 9 November are presented as an example (Fig. 9).

The outer four nested domains were simulated using a two-way interactive method from 00:00 UTC (08:00 LT) on 8 November, which was initialized using NCEP (National Centers for Environmental Prediction) FNL (Final Analysis Data) Operational Model Global Tropospheric Analyses data $\left(1^{\circ} \times 1^{\circ}\right.$, http://rda.ucar.edu/datasets/ds083.2/), while the inner domain was simulated using a one-way nested method from 12:00 UTC (20:00 LT) on 8 November, with initial and boundary fields provided by the fourth domain $(1.333 \mathrm{~km}$ grid). The model results show that, although the dominant synoptic wind direction was from the north during daytime and nighttime hours, weak mesoscale flows were observed. The model simulation showed a valley breeze in daytime (09:00 LT) on 9 November and a mountain breeze during nighttime (23:00 LT) hours. Therefore, the model simulation results further confirmed the influence of mountainvalley breezes on the redistribution of air pollutants between TW and TMS. Since $\mathrm{O}_{3}$ is a secondary pollution, as the air masses aged, secondary reactions occurred and the accumulated $\mathrm{O}_{3}$ pollution increased (Jiang et al., 2010). Mesoscale circulations, i.e., mountain-valley breezes, can bring freshlyemitted precursors such as VOCs and newly-formed $\mathrm{O}_{3}$ including that formed during the transit from the urban areas at the foot of the mountain (i.e., TW) to the summit (i.e., TMS) during daytime hours, which induced higher $\mathrm{O}_{3}$ levels at TMS.

In summary, based on the above discussion, it could be concluded that the higher $\mathrm{O}_{3}$ mixing ratios at TMS were attributed to the combination influence of NO titration, vertical meteorological conditions, and different atmospheric processes including mesoscale circulations and regional transport.

\subsection{The relationships between $\mathrm{O}_{3}$ and its precursors}

Different variations of $\mathrm{O}_{3}$ and other trace gases at the two sites indicated that relationships between $\mathrm{O}_{3}$ and its precursors may be different at the two sites. Correlations between $\mathrm{O}_{3}$ and reactive nitrogen $\left(\mathrm{NO}_{\mathrm{y}}\right)$ can provide useful information on the chemistry of photochemical $\mathrm{O}_{3}$ formation in a given location (Sillman et al., 1998, and references therein). In this study, NO was detected with a chemiluminescence analyzer (API, Model 200E), while $\mathrm{NO}_{2}$ was converted to NO by a hot molybdenum oxide (MoO) convertor and measured by the chemiluminescene detector. This analysis technique converts not only $\mathrm{NO}_{2}$ but also other reactive nitrogen species, including peroxyacetyl nitrate anhydride (PAN), organic nitrates and nitric acid to NO (Wang et al., 2001; 


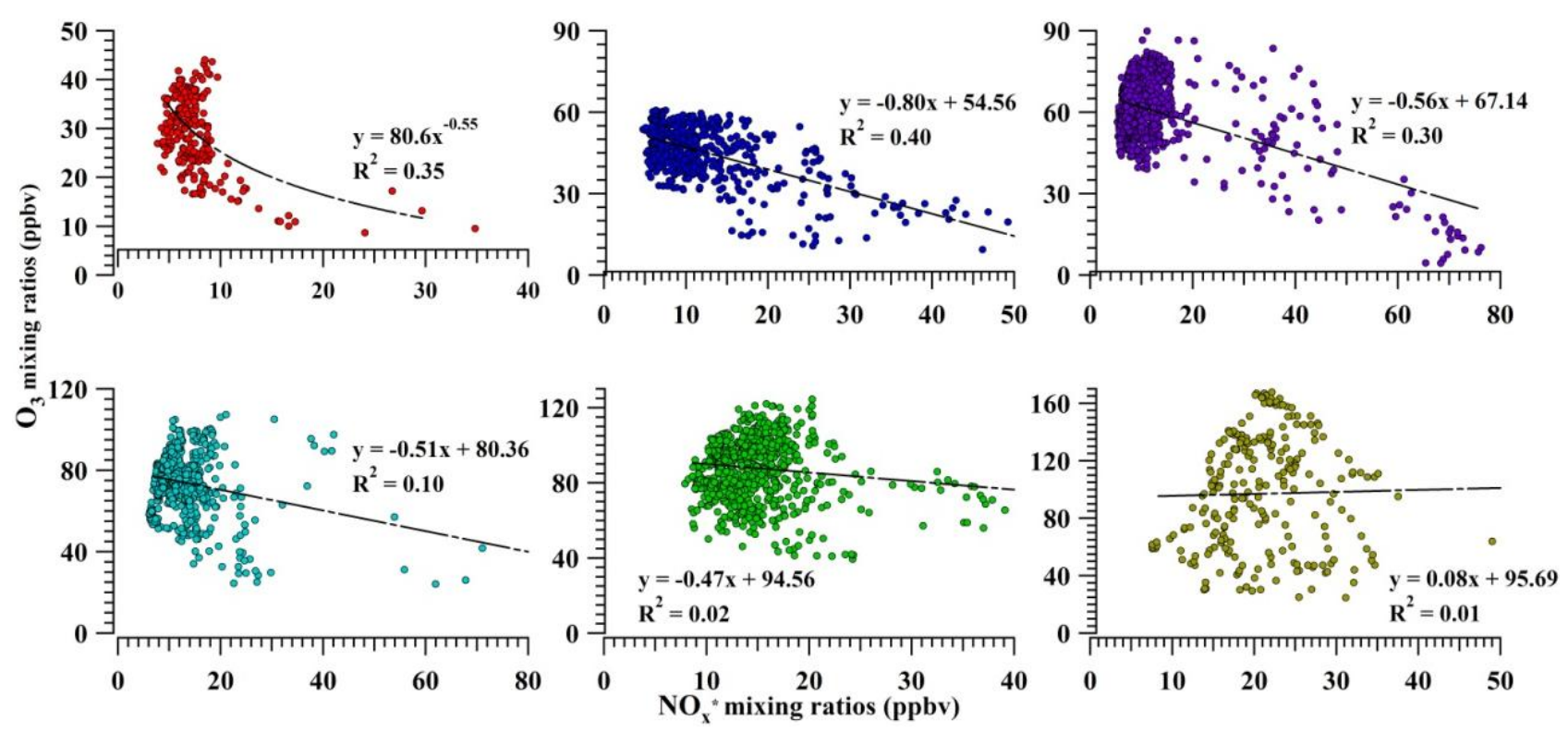

Fig. 10. Scatter plots of $\mathrm{O}_{3}$ (ppbv) vs. $\mathrm{NO}_{\mathrm{x}}^{*}$ (ppbv) for the days with the hourly peak $\mathrm{O}_{3}$ of (a) $20 \leq \mathrm{O}_{3} \leq 40$; (b) $40<\mathrm{O}_{3} \leq 60$; (c) $60<\mathrm{O}_{3} \leq$ 80 ; (d) $80<\mathrm{O}_{3} \leq 100$; (e) $100<\mathrm{O}_{3} \leq 120$; (f) $\mathrm{O}_{3}>120$ at TMS during sampling period.

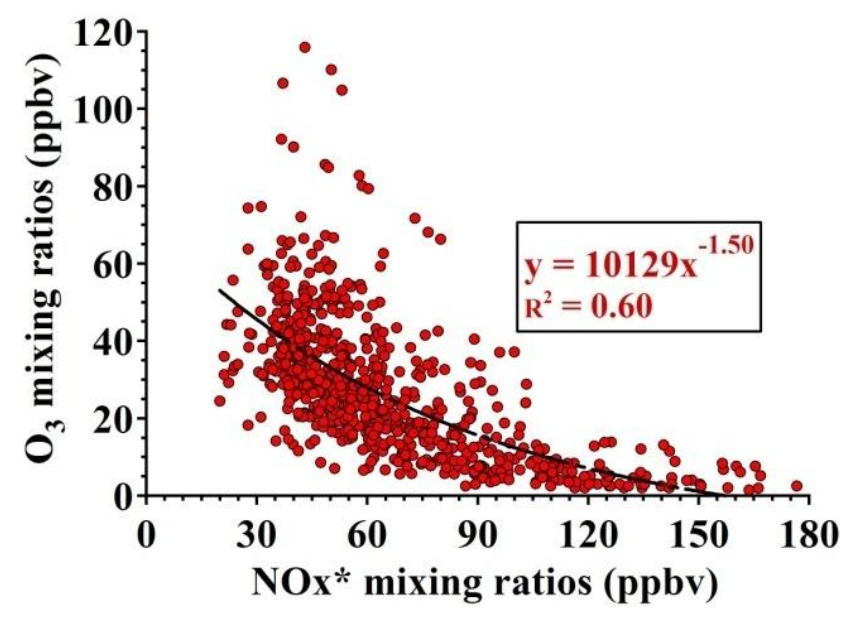

Fig. 11. Scatter plot of $\mathrm{O}_{3}$ (ppbv) vs. $\mathrm{NO}_{\mathrm{x}}^{*}$ (ppbv) at $\mathrm{TW}$ during the sampling period.

Steinbacher et al., 2007; Xu et al., 2013). The " $\mathrm{NO}_{\mathrm{x}}$ " measured, defining as " $\mathrm{NO}_{\mathrm{x}}^{*}$ ", is thus the sum of $\mathrm{NO}, \mathrm{NO}_{2}$ and other reactive nitrogen species described above, which approximate to $\mathrm{NO}_{\mathrm{y}}$ levels in the atmosphere (Wang et al., 2001; Steinbacher et al., 2007; Xu et al., 2013). As such, the measured $\mathrm{NO}_{\mathrm{x}}^{*}$ was taken as a surrogate of $\mathrm{NO}_{\mathrm{y}}$ in this study.

Since the range of peak $\mathrm{O}_{3}$ levels was large at TMS, correlations between $\mathrm{O}_{3}$ and $\mathrm{NO}_{\mathrm{x}}^{*}$ were investigated for six scenarios, which were divided according to different ranges of the peak $1 \mathrm{~h}$ average $\mathrm{O}_{3}$ mixing ratio. Figure 10 presents the correlations of $\mathrm{O}_{3}$ with $\mathrm{NO}_{\mathrm{x}}^{*}$ for the $10 \mathrm{~min}$ average data during the photochemical active hours (10:00-18:00 LT) in dif- ferent $\mathrm{O}_{3}$ scenarios. Negative correlations between $\mathrm{O}_{3}$ and $\mathrm{NO}_{\mathrm{x}}^{*}$ were found at TMS in the scenarios with lower $\mathrm{O}_{3}$ levels (the highest hourly average of 20-80 ppbv). This feature suggested a VOC-sensitive regime, where the photochemical $\mathrm{O}_{3}$ formation was suppressed as $\mathrm{NO}_{\mathrm{x}}$ mixing ratios increased (with average $\mathrm{NO}_{\mathrm{x}}^{*}$ levels changing from $7.8 \pm 0.4$ to $13.4 \pm 0.8 \mathrm{ppbv}$ ) in the corresponding scenarios. However, correlations deteriorated when $\mathrm{O}_{3}$ levels were higher (the highest hourly average of $80-140 \mathrm{ppbv}$ ), indicating that the suppression of $\mathrm{NO}_{\mathrm{x}}^{*}$ was reduced and photochemical $\mathrm{O}_{3}$ formation had changed from VOC-sensitive to both VOC- and $\mathrm{NO}_{\mathrm{x}}$-sensitive as $\mathrm{O}_{3}$ levels increased (Sillman et al., 2003).

Figure 11 shows the scatter plots of $\mathrm{O}_{3}$ and $\mathrm{NO}_{\mathrm{x}}^{*}$ during the photochemical active hours (10:00-18:00 LT) at TW. The results indicated that $\mathrm{O}_{3}$ concentrations were negatively correlated with $\mathrm{NO}_{\mathrm{x}}^{*}$, implying that $\mathrm{O}_{3}$ formation was primarily VOC-sensitive at TW (Sillman et al., 2003).

The ratio of VOCs $/ \mathrm{NO}_{\mathrm{x}}\left(\mathrm{NO}+\mathrm{NO}_{2}\right)$ is an important parameter to evaluate the relationships between $\mathrm{O}_{3}$ and its precursors (Sillman, 1999; Jenkin and Clemitshaw, 2000). Previous studies (Dodge, 1977; Finlayson-Pitts and Pitts, 1993; NESCAUM, 1995; Jenkin and Clemitshaw, 2000) found that the $\mathrm{VOCs} / \mathrm{NO}_{\mathrm{x}}\left(\mathrm{ppmC} \mathrm{ppm}^{-1}\right)$ ratio of 8 was an approximate reference point for evaluating relative benefits of $\mathrm{NO}_{\mathrm{x}}$ and VOC controls. $\mathrm{O}_{3}$ could be effectively reduced by a decrease of VOC under VOC-limited conditions, with the ratio of $\mathrm{VOCs} / \mathrm{NO}_{\mathrm{x}}<4 / 1$; and by a reduction of $\mathrm{NO}_{\mathrm{x}}$ concentration under $\mathrm{NO}_{\mathrm{x}}$-limited conditions, with the ratio of VOCs $/ \mathrm{NO}_{\mathrm{x}}>15 / 1$. In the transition area, when the ratios range from $4 / 1$ to $15 / 1$, a combination of VOCs and $\mathrm{NO}_{\mathrm{x}}$ controls was needed. Figure 12 shows the range of measured 

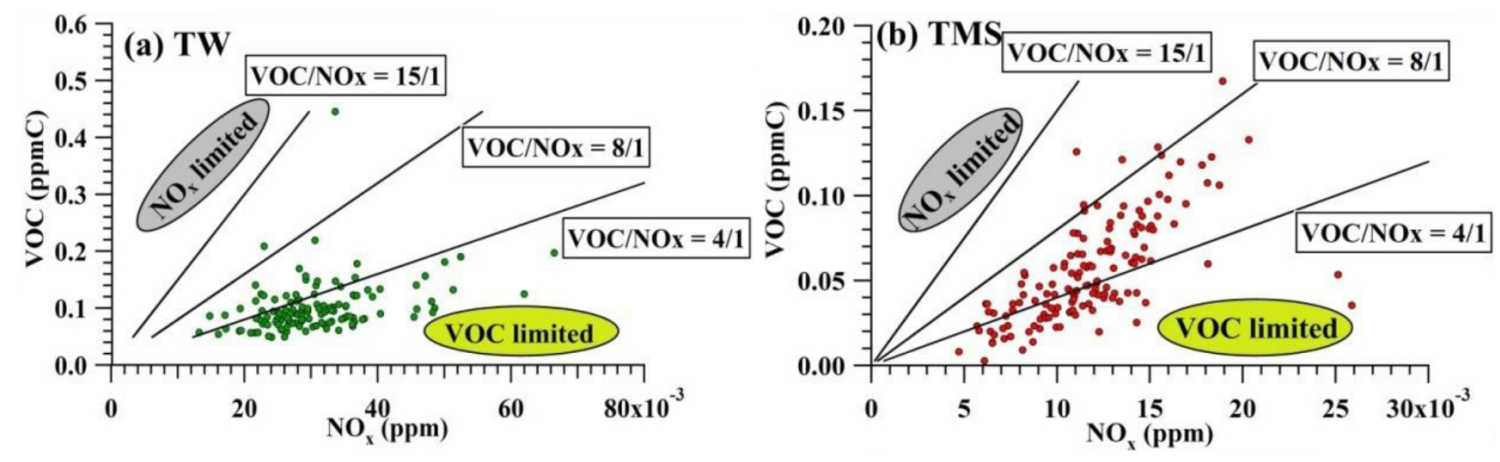

Fig. 12. Scatter plots of VOCs vs. $\mathrm{NO}_{\mathrm{x}}$ at daytime hours (07:00-18:00 LT) during sampling period at (a) TW and (b) TMS.
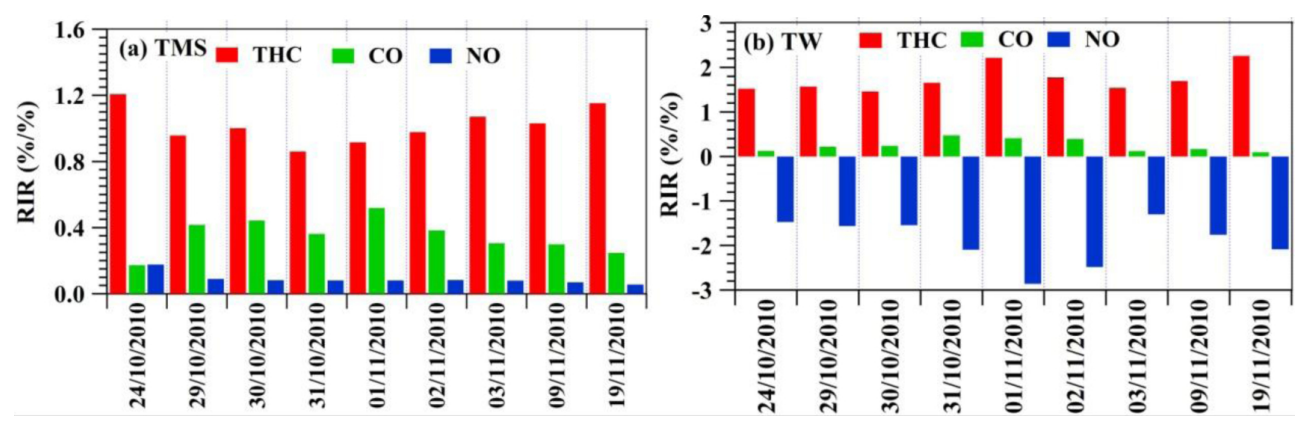

Fig. 13. RIR values of $\mathrm{O}_{3}$ precursors, i.e., THC (total hydrocarbons, consist of the VOCs described in Sect. 3.2.1), NO and CO at (a) TMS and (b) TW.

VOCs vs. $\mathrm{NO}_{\mathrm{x}}$ during daytime hours at TW and TMS. At $\mathrm{TW}$, about $82 \%$ of data points had a $\mathrm{VOC} / \mathrm{NO}_{\mathrm{x}}$ ratio within the range of 1 to 4 , while the ratio for $17 \%$ of data points was ranging from 4 to 8 . This result indicated that photochemi$\mathrm{cal} \mathrm{O}_{3}$ formation was mainly VOC-limited at TW; therefore, VOC reduction was most effective in reducing $\mathrm{O}_{3}$, and increasing $\mathrm{NO}_{\mathrm{x}}$ would suppress $\mathrm{O}_{3}$ formation. On the other hand, different characteristics were observed at TMS. Most of the data points (about $60 \%$ ) had the ratios in the transition area, with values of 4 to 15 , while the rest $40 \%$ of data points had values ranging from 1 to 4 . Additionally, about $96 \%$ of those data points with ratios ranging from 4 to 15 were found to range from 4 to 8 . The relatively higher ratios of VOCs $/ \mathrm{NO}_{\mathrm{x}}$ at TMS indicated that though VOCs were the most important compounds in the production of $\mathrm{O}_{3}$ at TMS, the contribution of $\mathrm{NO}_{\mathrm{x}}$ was also significant and a combination of $\mathrm{VOC}$ and $\mathrm{NO}_{\mathrm{x}}$ reductions may be warranted. However, it should be noted that the VOCs observed at the rural site, i.e., TMS, may be residues left from the VOCs in the upwind source areas due to photochemical reactions during transport. In addition, different VOC species react at different rates and with different reaction mechanisms, which induce the nonlinear dependency of $\mathrm{O}_{3}$ formation on $\mathrm{NO}_{\mathrm{x}}$ and VOCs. The above limitation could cause uncertainties for the analysis of the ratios of $\mathrm{VOCs} / \mathrm{NO}_{\mathrm{x}}$ at TMS.
Therefore, in order to investigate the $\mathrm{O}_{3}$-precursor relationship in more details, an observation-based model (OBM) was applied in this study. The OBM model, developed by Cardelino and Chameides (1995), uses concentrations of $\mathrm{O}_{3}$ and its precursors (i.e., VOCs, $\mathrm{NO}$ and $\mathrm{CO}$ ), as well as meteorological data measured as a function of time at given sites. The calculated relative incremental reactivity (RIR) function extracted from the OBM model could be used to investigate the change of $\mathrm{O}_{3}$ formation according to the change of its precursors' concentrations in different environments (Chameides and Demerjian, 2000; Chou et al., 2006; Zhang et al., 2007, 2008; Cheng et al., 2010; Ling et al., 2011). In this study, measured data at 10:00-18:00 LT on the selected $\mathrm{O}_{3}$ episode days at TMS and TW were input into the OBM model to calculate the sensitivity of $\mathrm{O}_{3}$ production to its precursors, i.e., RIR. Figure 13 presents the RIRs for $\mathrm{O}_{3}$ precursors at TMS and TW. It was found that VOC showed the highest RIR values at the both sites, meaning that VOC was the most important group in $\mathrm{O}_{3}$ production. In addition, relatively higher RIRs were found for $\mathrm{CO}$ at TMS, indicating that $\mathrm{CO}$ could have a significant impact on the $\mathrm{O}_{3}$ formation when it is transported from the upwind areas (Ling et al., 2011). Interestingly, the RIRs of NO at TMS were positive but small, indicating that $\mathrm{NO}$ also had some influence on $\mathrm{O}_{3}$ production. On the other hand, the RIRs of NO were negative at TW, indicating a strong VOC-limited regime. Based on the 
$\mathrm{VOC} / \mathrm{NO}_{\mathrm{x}}$ ratio analysis and the OBM results, it was concluded that photochemical $\mathrm{O}_{3}$ formation at TMS was mostly influenced by VOCs, with measurable impact of NO, while $\mathrm{O}_{3}$ production at TW was generally limited by the concentrations of VOCs.

\section{Conclusions}

Simultaneous systematic measurements of air pollutants were conducted at the foot and near the summit of a mountain in Hong Kong from September to November 2010. The levels of primary air pollutants (i.e., $\mathrm{CO}, \mathrm{SO}_{2}, \mathrm{NO}_{\mathrm{x}}$ and $\mathrm{VOCs}$ ) were lower at TMS than at TW, while $\mathrm{O}_{3}$ was greater at TMS than at TW. Only one $\mathrm{O}_{3}$ episode day and three near$\mathrm{O}_{3}$ episode days were observed at TW, while a total twentyone (21) $\mathrm{O}_{3}$ episode days were found at TMS. The relatively higher levels of $\mathrm{O}_{3}$ at TMS were attributed to the combination effects of NO titration, vertical meteorological conditions, regional transport and mesoscale circulations. On the other hand, the correlations over the entire ranges of observed $\mathrm{O}_{3}$ with $\mathrm{NO}_{\mathrm{x}}^{*}$, the ratio of $\mathrm{VOCs} / \mathrm{NO}_{\mathrm{x}}$ and the OBM modeling results implied that photochemical $\mathrm{O}_{3}$ formation at TMS was mostly influenced by VOCs, with a measurable effect of $\mathrm{NO}_{\mathrm{x}}$, while $\mathrm{O}_{3}$ production at TW was generally limited by the concentrations of VOCs.

Acknowledgements. This project is supported by the Research Grants Council of the Hong Kong Special Administrative Region via grants PolyU5179/09E and N_PolyU545/09. This study is partly supported by the internal grants of the Hong Kong Polytechnic University (A-PK25 and 1-ZV7A). The authors acknowledge the strong support of the European Commission, Airbus, and the Airlines (Lufthansa, Austrian, Air France) who carry free of charge the MOZAIC equipment and perform the maintenance since 1994. MOZAIC is presently funded by INSU-CNRS (Institute National des Sciences del'Univers - Centre National de la Recherche Scientifique, France), Météo-France, and FZJ (Forschungszentrum Jülich, Germany). The Final Analysis Data (FNL) was obtained from NOAA CDC. We are grateful to Yu Yufan, Choi Yu-Leung, Chan Wai-Lun, Tam Wai Fan, Shen Yi and Liu Qian for their technical support. The comments from anonymous reviewers are highly appreciated.

Edited by: A. B. Guenther

\section{References}

AFCD (Agriculture, Fisheries and conservation Department), available at: http://www.afcd.gov.hk/, 2008.

Atkinson, R.: Gas-phase tropospheric chemistry of volatile organic compounds: 1. Alkanes and alkenes, J. Phys. Chem. Ref. Data, 26, 215-290, 1997.

Barletta, B., Meinardi, S., Simpson, I. J., Zou, S. C., Rowland, F. S., and Blake, D. R.: Ambient mixing ratios of nonmethane hydrocarbons (NMHCs) in two major urban centers of the Pearl
River Delta (PRD) region: Guangzhou and Dongguan, Atmos. Environ., 42, 4393-4408, 2008.

Bloss, C., Wagner, V., Jenkin, M. E., Volkamer, R., Bloss, W. J., Lee, J. D., Heard, D. E., Wirtz, K., Martin-Reviejo, M., Rea, G., Wenger, J. C., and Pilling, M. J.: Development of a detailed chemical mechanism (MCMv3.1) for the atmospheric oxidation of aromatic hydrocarbons, Atmos. Chem. Phys., 5, 641-664, doi:10.5194/acp-5-641-2005, 2005.

Burley, J. D. and Bytnerowicz, A.: Surface ozone in the white mountains of California, Atmos. Environ., 45, 4591-4602, 2011.

Cardelino, C. A. and Chameides, W. L.: An observation-based model for analyzing ozone precursor relationships in the urban atmosphere, J. Air Waste Manage., 45, 161-180, 1995.

Chameides, W. L. and Demerjian, K. L.: An Assessment of Tropospheric Ozone Pollution: a North America Perspective, Palo Alto, California, USA, 2000.

Chan, C. Y. and Chan, L. Y.: Effect of meteorology and air pollutant transport on ozone episodes at a subtropical coastal Asian city, Hong Kong, J. Geophys. Res., 105, 20707-20724, 2000.

Chan, L. Y., Chan, C. Y., and Qin, Y.: Surface ozone pattern in Hong Kong, J. Appl. Meteorol., 37, 1153-1165, 1998a.

Chan, L. Y., Liu, H. Y., and Lam, K. S.: Analysis of the seasonal behavior of tropospheric ozone at Hong Kong, Atmos. Environ., 32, 159-168, 1998b.

Chen, C. L., Tsuang, B. J., Tu, C. Y., Cheng, W. L., and Lin, W. D.: Wintertime vertical profiles of air pollutants over a suburban area in central Taiwan, Atmos. Environ., 36, 2049-2059, 2002.

Chen, F. and Dudhia, J.: Coupling an Advanced Land SurfaceHydrology Model with the Penn State-NCAR MM5 Modeling System. Part I: Model implementation and sensitivity, Mon. Weathrt Rev., 129, 569-585, 2001.

Cheng, H. R., Guo, H., Wang, X. M., Saunders, S. M., Lam, S. H. M., Jiang, F., Wang, T., Ding, A., Lee, S., and Ho, K. F.: On the relationship between ozone and its precursors in the Pearl River Delta: application of an observation-based model (OBM), Environ. Sci. Pollut. Res., 17, 547-560, 2010.

Chou, C. C. K., Liu, S. C., Lin, C. Y., Shiu, C. J., and Chang, K. H.: The trend of surface ozone in Taipei, Taiwan, and its causes: Implications for ozone control strategies, Atmos. Environ., 40, 3898-3908, 2006.

Chou, M. D. and Suarez, M. J.: An efficient thermal infrared radiation parameterization for use in general circulation models, NASA Tech. Memo. 104606, 3, 85 pp., 1994.

Colman, J. J., Swanson, A., Meinardi, S., Sive, B. C., Blake, D. R., and Rowland, F. S.: Description of the analysis of a wide range of volatile organic compounds in whole air samples collected during PEM-Tropics A and B, J. Anal. Chem., 73, 3723-3731, 2001.

Crowley, J. N., Schuster, G., Pouvesle, N., Parchatka, U., Fischer, H., Bonn, B., Bingemer, H., and Lelieveld, J.: Nocturnal nitrogen oxides at a rural mountain-site in south-western Germany, Atmos. Chem. Phys., 10, 2795-2812, doi:10.5194/acp-10-27952010, 2010.

Ding, A. J., Wang, T., Zhao M., Wang, T. J., and Li, Z. K.: Simulation of sea-land breezes and a discussion of their implications on the transport of air pollution during a multi-day ozone episode in the Pearl River Delta of China, Atmos. Environ., 38, 6737-6750, 2004.

Ding, A. J., Wang, T., Thouret, V., Cammas, J.-P., and Nédélec, P.: Tropospheric ozone climatology over Beijing: analysis of aircraft 
data from the MOZAIC program, Atmos. Chem. Phys., 8, 1-13, doi:10.5194/acp-8-1-2008, 2008.

Dodge, M. C.: Combined use of modeling techniques and smog chamber data to derive ozone-precursor relationships. International Conference on Photochemical Oxidant Pollution and its Control: Proceedings, Vol. II B, EPA/600/3-77-001b, US Environmental Protection Agency, Research Triange Park, NC, 881889, 1977.

Done, J., Davis, C., and Weisman, M.: The next generation of NWP: Explicit forecasts of convection using the Weather Research and Forecast (WRF) model, Atmos. Sci. Lett., 5, 110-117, doi:10.1002/asl.72, 2004.

Doran, J. C., Berkowitz, C. M., Coulter, R. L., Spicer, C. W., and Shaw, W. J.: The 2001 Phoenix Sunrise experiment: vertical mixing and chemistry during the morning transition in Phoenix, Atmos. Environ., 37, 2365-2377, 2003.

Ehhalt, D. H., Rohrer, F., Wahner, A., Prather, M. J., and Blake, D. R.: On the use of hydrocarbons for the determination of tropospheric OH concentrations, J. Geophys. Res., 103, 18981-18997, 1998.

Evtyugina, M. G., Nunes, T., Alves, C., and Marques, M. C.: Photochemical pollution in a rural mountainous area in the northeast of Portugal, Atmos. Res., 92, 151-158, 2009.

Finlayson-Pitts, B. J. and Pitts, N.: VOCs, $\mathrm{NO}_{\mathrm{x}}$ and ozone production, J. Air Waste Manage., 43, 1093-1101, 1993.

Fu, P. Q., Kawamura, K., Kanaya, Y., and Wang, Z. F.: Contributions of biogenic volatile organic compounds to the formation of secondary organic aerosols over Mt. Tai, Central East China, Atmos. Environ., 44, 4817-4826, 2010.

Gao, J., Wang, T., Ding, A. J., and Liu, C. B.: Observational study of ozone and carbon monoxide at the summit of mount Tai (1534 m a.s.l.) in central-eastern China, Atmos. Environ., 39, 4779-4791, 2005.

Grell, G. A. and Dévényi, D.: A generalized approach to parameterizing convection combining ensemble and data assimilation techniques, Geophys. Res. Lett., 29, 1693, doi:10.1029/2002GL015311, 2002.

Guo, H., Jiang, F., Cheng, H. R., Simpson, I. J., Wang, X. M., Ding, A. J., Wang, T. J., Saunders, S. M., Wang, T., Lam, S. H. M., Blake, D. R., Zhang, Y. L., and Xie, M.: Concurrent observations of air pollutants at two sites in the Pearl River Delta and the implication of regional transport, Atmos. Chem. Phys., 9, 73437360, doi:10.5194/acp-9-7343-2009, 2009.

Guo, H., Ling, Z. H., Simpson, I. J., Blake, D. R., and Wang, D. W.: Observations of isoprene, methacrolein (MAC) and methyl vinyl ketone (MVK) at a mountain site in Hong Kong, J. Geophys. Res., 117, D19303, doi:10.1029/2012JD017750, 2012.

Ho, K. F., Lee, S. C., Ho, W. K., Blake, D. R., Cheng, Y., Li, Y. S., Ho, S. S. H., Fung, K., Louie, P. K. K., and Park, D.: Vehicular emission of volatile organic compounds (VOCs) from a tunnel study in Hong Kong, Atmos. Chem. Phys., 9, 7491-7504, doi:10.5194/acp-9-7491-2009, 2009.

Ho, K. F., Lee, S. C., Guo, H., Tsai, W. Y.: Seasonal and diurnal variations of volatile organic compounds (VOCs) in the atmosphere of Hong Kong, Sci. Total Environ., 322, 155-166, 2004.

Hong Kong Environmental Protection Department (HKEPD): An overview on air quality and air pollution control in Hong Kong, http://www.epd.gov.hk/epd/english/environmentinhk/air/ air_maincontent.html, 2010.
Hong Kong Environmental Protection Department (HKEPD): Air Quality in Hong Kong 2011 (Preliminary Report), Air Science Group, Environmental Protection Department, the Government of the Hong Kong Special Administrative Region, 2012.

Hong, S. Y., Dudhia, J., and Chen, S.-H.: A revised approach to icemicrophysical processes for the bulk parameterization of cloud and precipitation, Mon. Weather Rev., 132, 103-120, 2004.

Hong, S. Y., Noh, Y., and Dudhia, J.: A new vertical diffusion package with explicit treatment of entrainment processes, Mon. Weather Rev., 134, 2318-2341, 2006.

Huang, J. P., Fung, J. C. H., and Lau, A. K. H.: Integrated processes analysis and systematic meteorological classification of ozone episodes in Hong Kong, J. Geophys. Res., 111, D20309, doi:10/1029/2005JD007012, 2006.

IPCC (Intergovernmental Panel on Climate Change): The Physical Science Basis. Contribution of Working Group I to the Fourth Assessment Report of the Intergovernmental Panel on Climate Change, Cambridge Univ. Press, Cambridge, UK, 2007.

Jenkin, M. E. and Clemitshaw, K. C.: Ozone and other secondary photochemical pollutants: chemical processes governing their formation in the planetary boundary layer, Atmos. Environ., 34, 2499-2527, 2000.

Jenkin, M. E., Saunders, S. M., Wagner, V., and Pilling, M. J.: The tropospheric degradation of volatile organic compounds: A protocol for mechanism development, Atmos. Environ., 31, 81-107, 1997.

Jenkin, M. E., Saunders, S. M., Wagner, V., and Pilling, M. J.: Protocol for the development of the Master Chemical Mechanism, MCM v3 (Part B): tropospheric degradation of aromatic volatile organic compounds, Atmos. Chem. Phys., 3, 181-193, doi:10.5194/acp-3-181-2003, 2003.

Jiang, F., Wang, T. J., Wang, T. T., Xie, M., and Zhao, H.: Numerical modeling of a continuous photochemical pollution episode in Hong Kong using WRF-chem., Atmos. Environ., 42, 8717-8727, 2008.

Jiang, F., Guo, H., Wang, T. J., Cheng, H. R., Wang, X. M., Simpson, I. J., Ding, A. J., Saunders, S. M., Lam, S. H. M., and Blake, D. R.: An ozone episode in the Pearl River Delta: Field observation and model simulation, J. Geophys. Res., 115, D22305, doi:10.1029/2009JD013583, 2010.

Jobson, B. T., Mckeen, S. A., and Parrish, D. D.: Spatial and temporal variability of nonmethane hydrocarbon mixing ratios and their relation to photochemical lifetime, J. Geophys. Res., 103, 13557-13567, 1998.

Lam, S. H. M., Ling, Z. H., Guo, H., Saunders, S. M., Jiang, F., Wang, X. M., and Wang, T. J.: Modelling VOC source impacts on high ozone episode days observed at a mountain summit in Hong Kong under the influence of mountain-valley breezes, J. Environ. Manage., submitted, 2013.

Li, J., Pochanart, P., Wang, Z. F., Liu, Y., Yamaji, K., Takigawa, M., Kanaya, Y., and Akimoto, H.: Impact of chemical production and transport on summertime diurnal ozone behavior at a mountainous site in North China Plain, Sola, 4, 121-124, 2008.

Lin, C. H., Lai, C. H., Wu, Y. L., Lai, H. C., and Lin, P. H.: Vertical ozone distributions observed using tethered ozonesondes in a coastal industrial city, Kaohsiung, in southern Taiwan, Environ. Monit. Assess., 127, 253-270, 2007.

Ling, Z. H., Guo, H., Cheng, H. R., and Yu, Y. F.: Sources of ambient volatile organic compounds and their contributions to 
photochemical ozone formation at a site in the Pearl River Delta, southern China, Environ. Pollut., 159, 2310-2319, 2011.

Liu, H. P., Chan, J. C. L., and Cheng, A. Y. S.: Internal boundary layer structure under sea-breeze conditions in Hong Kong, Atmos. Environ., 35, 683-692, 2000.

Liu, Y., Shao, M., Kuster, W. C., Goldan, P. D., Li, X. H., Lu, S. H., and de Gouw, J. A.: Source identification of reactive hydrocarbons and oxygenated VOCs in the summertime in Beijing, Environ. Sci. Technol., 43, 75-81, 2009.

Ma, Z. Q., Zhang, X. L., Xu, J., Zhao, X. J., and Wei, M.: Characteristics of ozone vertical profile observed in the boundary layer around Beijing in autumn, J. Environ. Sci., 23, 1316-1324, 2011.

Mlawer, E. J., Taubman, S. J., Brown, P. D., Iacono, M. J., and Clough, S. A.: Radiative transfer for inhomogeneous atmospheres: RRTM, a validated correlated-k model for the longwave, J. Geophys. Res., 102D, 16663-16682, 1997.

Monteiro, A., Strunk, A., Carvalho, A., Tchepep, O., Miranda, A. I., Borrego, C., Saavedra, S., Rpdríguez, A., Souto, J., Casares, J., Friese, E., and Elbern, H.: Investigating a high ozone episode in a rural mountain site, Environ. Pollut., 162, 176-189, 2012.

NESCAUM (Northeast States for Coordinated Air Use Management), 1995: Preview of 1994.

NRC (National Research Council): The effects of meteorological on tropospheric ozone, in: Rethinking the ozone problem in urban and regional air pollution, National Academy Press, Washington, DC, USA, 1991.

Ou Yang, C. F., Liu, N. H., Sheu, G. R., Lee, C. T., and Wang, J. L.: Seasonal and diurnal variations of ozone at a high-altitude mountain baseline station in East Asia, Atmos. Environ., 46, 279-288, 2012.

Parrish, D. D., Buhr, M. P., Trainer, M., Northon, R. B., Shimshock, J. P., Fehsenfeld, F. C., Anlauf, K. G., Bottenheim, J. W., Tang, Y. Z., Wiebe, H. A., Roberts, J. M., Tanner, R. L., Newman, L., Bowersox, V. C., Olszyna, K. J., Bailey, E. M., Rodgers, M. O., Wang, T., Berresheim, H., Roychowdhury, U. K., and Demerjiani, K. L.: The total reactive oxidized nitrogen levels and their partitioning between the individual species at six rural sites in eastern North America, J. Geophys. Res., 98, 2927-2939, 1993.

Pochanart, P., Akimoto, H., Kajii, Y., Potemkin, V. M., and Khodzher, V. T.: Regional background ozone and carbon monoxide variations in remote Siberia/east Asia, J. Geophys. Res., 108, 4028, doi:10.1029/2001JD001412, 2003.

PORG (Photochemical Oxidants Review Group): Ozone in the United Kingdom, Fourth Report of the UK photochemical Oxidants review group, Department of the Environment, Transport and the Regions, London, 1997.

Reeves, C. E., Slemr, J., Oram, D. E., Worton, D., Penkett, S. A., Stewart, D. J., Purvis, R., Watson, N., Hopkins, J., Lewis, A., Methven, J., Blake, D. R., and Atlas, E.: Alkyl nitrates in outflow from North America over the North Atlantic during Intercontinental Transport of Ozone and Precursors 2004, J. Geophys. Res., 112, D10S37, doi:10.1029/2006JD007567, 2007.

Roberts, J. M., Bertman, S. B., Parrish, D. D., Fehsenfeld, F. C., Jobson, B. T., and Niki, H.: Measurement of alkyl nitrates at Chebogue Point, Nova Scotia during the 1993 North Atlantic Regional Experiment (NARE) intensive, J. Geophys. Res., 103, 13569-13580, 1998.

Saunders, S. M., Jenkin, M. E., Derwent, R. G., and Pilling, M. J.: Protocol for the development of the Master Chemical Mech- anism, MCM v3 (Part A): tropospheric degradation of nonaromatic volatile organic compounds, Atmos. Chem. Phys., 3, 161-180, doi:10.5194/acp-3-161-2003, 2003.

Scott, B. and Ahmet, P.: Influence of synoptic and mesoscale meteorology on ozone pollution potential for San Joaquin Valley of California, Atmos. Environ., 43, 1779-1788, 2009.

Sillman, S.: The relation between ozone, $\mathrm{NO}_{\mathrm{x}}$ and hydrocarbons in urban and polluted rural environments, Atmos. Environ., 33 , 1821-1845, 1999.

Sillman, S., He, D. Y., and Pippin, M. R.: Model correlations for ozone, reactive nitrogen, and peroxides for Nashville in comparison with measurements: Implications for $\mathrm{O}_{3}-\mathrm{NO}_{\mathrm{x}}$-hydrocarbon chemistry, J. Geophys. Res., 103, 22629-22644, 1998.

Sillman, S., Vautard, R., Menut, L., and Kley, D.: $\mathrm{O}_{3}-\mathrm{NO}_{\mathrm{X}}-$ VOC sensitivity and $\mathrm{NO}_{\mathrm{x}}-\mathrm{VOC}$ indicators in Paris: Results from models and atmospheric pollution over the Paris Area (ESQUIF) measurements, J. Geophys. Res., 108, 8563, doi:10.1029/2002JD001561, 2003.

Simpson, I. J., Blake, N. J., Barletta, B., Diskin, G. S., Fuelberg, H. E., Gorham, K., Huey, L. G., Meinardi, S., Rowland, F. S., Vay, S. A., Weinheimer, A. J., Yang, M., and Blake, D. R.: Characterization of trace gases measured over Alberta oil sands mining operations: 76 speciated $\mathrm{C}_{2}-\mathrm{C}_{10}$ volatile organic compounds (VOCs), $\mathrm{CO}_{2}, \mathrm{CH}_{4}, \mathrm{CO}, \mathrm{NO}, \mathrm{NO}_{2}, \mathrm{NO}_{\mathrm{y}}, \mathrm{O}_{3}$ and $\mathrm{SO}_{2}$, Atmos. Chem. Phys., 10, 11931-11954, doi:10.5194/acp-10-11931-2010, 2010.

Skamarock, W. C. and Klemp, J. B.: A time split non hydrostatic atmospheric model for weather research and forecasting applications, J. Comput. Phys., 227, 7, 3465-3485, 2008.

So, K. L. and Wang, T.: On the local and regional influence on ground-level ozone concentrations in Hong Kong, Environ. Pollut., 123, 307-317, 2003.

Steinbacher, M., Zellweger, C., Schwarzenbach, B., Bugmann, S., Buchmann, B., Ordónez, C., Prevot, A., and Hueglin, C.: Nitrogen oxide measurements at rural sites in Switzerland: Bias of conventional measurement techniques, J. Geophys. Res., 112, D11307, doi:10.1029/2001JD001412, 2007.

Steven, E. K., Benjamin, S. G., McGinley, J. A., Brown, J. M., Schultz, P., Szoke, E. J., Smirnova, T. G., Shaw, B. L., Birkenheuer, D., Albers, S., Peckham, S., and Grell, G.: Real-time Applications of the WRF Model at the Forecast Systems Laboratory, 84th AMS Annual Meeting, Seattle, USA, 10-15 January 2004.

Tang, G., Wang, Y., Li, X., Ji, D., Hsu, S., and Gao, X.: Spatialtemporal variations in surface ozone in Northern China as observed during 2009-2010 and possible implications for future air quality control strategies, Atmos. Chem. Phys., 12, 2757-2776, doi:10.5194/acp-12-2757-2012, 2012.

Tang, J. H., Chan, L. Y., Chan, C. Y., Li, Y. S., Chang, C. C., Wang, X. M., Zou, S. C., Barletta, B., Blake, D. R., and Wu, D.: Implications of changing urban and rural emissions on non-methane hydrocarbons in the Pearl River Delta region of China, Atmos. Environ., 42, 3780-3794, 2008.

Tseng, K. H., Chen, C. L., Lin, M. D., Chang, K. H., and Tsuang, B. J.: Vertical profile of ozone and accompanying air pollutant concentrations observed at a downwind foothill site of industrial and urban areas, Aerosol Air Qual. Res., 9, 421-434, 2009.

Tsai, W. Y., Chan, L. Y., Blake, D. R., and Chu, K. W.: Vehicular fuel composition and atmospheric emissions in South China: Hong Kong, Macau, Guangzhou, and Zhuhai, Atmos. Chem. Phys., 6, 3281-3288, doi:10.5194/acp-6-3281-2006, 2006. 
Turnipseed, A. A., Anderson, D. E., Burns, S., Blanken, P. D., and Monson, R. K.: Airflows and turbulent flux measurements in mountainous terrain Part 2: mesoscale effects, Agr. Forest Meterol., 125, 187-205, 2004.

Wang, T. and Kwok, J. Y. H.: Measurement and analysis of a multiday photochemical smog episode in the Pearl River Delta of China, J. Appl. Meteorol., 42, 404-416, 2003.

Wang, T., Cheung, V. T. F., Lam, K. S., Kok, G. L., and Harris, J. M.: The characteristics of ozone and related compounds in the boundary layer of the South China coast: temporal and vertical variations during autumn season, Atmos. Environ., 35, 27352746, 2001.

Wang, T., Poon, C. N., Kwok, Y. H., and Li, Y. S.: Characterizing the temporal variability and emission patterns of pollution plumes in the Pearl River Delta of China, Atmos. Environ., 37, 3539-3550, 2003.

Wang, T., Guo, H., Blake, D. R., Kwok, Y. H., Simpson, I. J., and Li, Y. S.: Measurements of trace gases in the inflow of South China Sea background air and outflow of regional pollution at Tai O, Southern China, J. Atmos. Chem., 52, 295-317, 2005.

Wang, T., Wong, H. L. A., Tang, J., Ding, A., Wu, W. S., and Zhang, X. C.: On the origin of surface ozone and reactive nitrogen observed at remote site in the northeastern QinghaiTibetan Plateau, western China, J. Geophys. Res., 111, D08303, doi:10.1029/2005JD006527, 2006.

Wang, T., Wei, X. L., Ding, A. J., Poon, C. N., Lam, K. S., Li, Y. S., Chan, L. Y., and Anson, M.: Increasing surface ozone concentrations in the background atmosphere of Southern China, 19942007, Atmos. Chem. Phys., 9, 6217-6227, doi:10.5194/acp-96217-2009, 2009.

Warneke, C. and de Gouw, J. A.: Organic trace gas composition of the marine boundary layer over the northwest India Ocean in April 2000, Atmos. Environ., 35, 5923-5933, 2001.

Xu, Z., Wang, T., Xue, L. K., Louie, P., Luk, C., Gao, J., Wang, S. L., Chai, F. H., an Wang, W. X.: Evaluating the uncertainties of thermal catalytic conversion for measuring atmospheric nitrogen dioxide at four polluted sites in China, Atmos. Environ., doi:10.1016/j.atmosenv.2012.09.043, in press, 2013.

Xue, L. K., Wang, T., Zhang, J. M., Zhang, X. C., Delig-Geer, Poon, C. N., Ding, A. J., Zhou, X. H., Wu, W. S., Tang, J., Zhang, Q. Z., and Wang, W. X.: Source of surface ozone and reactive nitrogen speciation at Mount Waliguan in Western China: New insights from the 2006 summer study, J. Geophys. Res., 116, D07306, doi:10.1029/2010JD014735, 2011.
Yuan, B., Shao, M., de Gouw, J., Parrish, D. D., Lu, S. H., Wang, M., Zeng, L. M., Zhang, Q., Song, Y., Zhang, J. B., and Hu, M.: Volatile Organic Compounds (VOCs) in Urban Air: How Chemistry Affects the Interpretation of Positive Matrix Factorization (PMF) Analysis, J. Geophys. Res., 117, D24, doi:10.1029/2012JD018236, 2012.

Zanis, P., Ganser, A., Zellweger, C., Henne, S., Steinbacher, M., and Staehelin, J.: Seasonal variability of measured ozone production efficiencies in the lower free troposphere of Central Europe, Atmos. Chem. Phys., 7, 223-236, doi:10.5194/acp-7-223-2007, 2007.

Zellweger, C., Forrer, J., Hofer, P., Nyeki, S., Schwarzenbach, B., Weingartner, E., Ammann, M., and Baltensperger, U.: Partitioning of reactive nitrogen (NOy) and dependence on meteorological conditions in the lower free troposphere, Atmos. Chem. Phys., 3, 779-796, doi:10.5194/acp-3-779-2003, 2003.

Zhang, D. and Anthes, R. A.: A high-resolution model of the planetary boundary layer - sensitivity tests and comparison with SESAME-79 data, J. Appl. Meteorol., 21, 1594-1609, 1982.

Zhang, J., Wang, T., Chameides, W. L., Cardelino, C., Kwok, J., Blake, D. R., Ding, A., and So, K. L.: Ozone production and hydrocarbon reactivity in Hong Kong, Southern China, Atmos. Chem. Phys., 7, 557-573, doi:10.5194/acp-7-557-2007, 2007.

Zhang, L. F. and Zhang, M.: Study of the sea-land breeze system in Hong Kong, HKMetS Bulletin, 7, 22-42, 1997.

Zhang, Y. H., Su, H., Zhong, L. J., Cheng, Y. F., Zeng, L. M., Wang, X. S., Xiang, Y. R., Wang, J. L., Gao, D. F., Shao, M., Fan, S. J., and Liu, S. C.: Regional ozone pollution and observation-based approach for analyzing ozone-precursor relationship during the PRIDE-PRD2004 campaign, Atmos. Environ., 42, 6203-6218, 2008.

Zhang, Y. L., Wang, X. M., Blake, D. R., Li, L. F., Zhang, Z., Wang, Shao, Y., Guo, H., Lee, S. C., Guo, B., Chan, L. Y., Wu, D., and Rowland, F. S.: Aromatic hydrocarbons as ozone precursors before and after outbreak of the 2008 financial crisis in the Pearl River Delta region, south China, J. Geophys. Res.-Atmos., 117, D15306, doi:10.1029/2011JD017356, 2012.

Zhao, Y., Shao, M., Wang, C., Wang, B. G., Lu, S. H., and Zhong, L. J.: Characterizing spatial patterns of $\mathrm{NO}_{\mathrm{x}}, \mathrm{SO}_{2}$ and $\mathrm{O}_{3}$ in Pearl River Delta by Passive Sampling, J. Environ. Sci., 32, 324-329, 2011. 